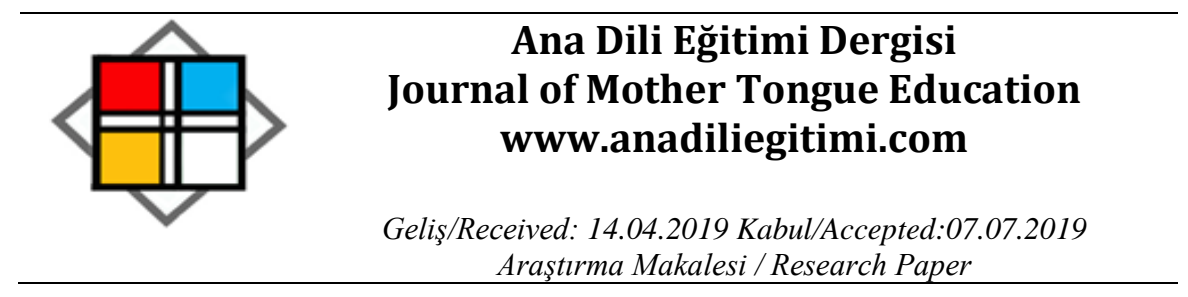

\title{
Öyküleyici Metinler Aracılığıyla Eleştirel Düşünme Becerilerini Değerlendirmeye Yönelik Bir Rubrik $^{*}$
}

\author{
Funda Amanvermez INCIRKUŞ ${ }^{* *}$ \\ Latif BEYRELi* ${ }^{* * *}$
}

\begin{abstract}
Öz
Bu çalışmada öyküleyici metinler aracılığıyla öğrencilerin eleştirel düşünme becerilerini değerlendirmeye yönelik analitik bir rubrik geliştirme sürecine yer verilmiştir. Rubrik, içeriği anlama (tanımlama, yorumlama) ve derinlemesine anlama (analiz, çıkarım, açıklama, varsayımda bulunma, değerlendirme) olmak üzere 2 boyut ve 7 kriterden oluşmaktadır. Çalışma, uzman görüşüne dayalı nitel bir çalışmadır. Çalışma grubu ölçüt örnekleme ile ortaokul öğrencileri $(n=202)$ olarak belirlenmiştir. Ölçeğin kapsam geçerliği için Lawshe tekniği kullanılmıştır. İçeriği anlama boyutunun kapsam geçerlik indeksi (KGi) 0.89; derinlemesine anlama boyutunun ise 0.87 olarak hesaplanmıştır. Çalışmanın güvenirliği "bağımsız değerlendirmeciler arası uyum güvenirliği" ile sağlanmıştır. Pearson korelasyon analizi sonucunda değerlendirmecilerin eleştirel düşünme kriterlerine ilişkin puan ortalamaları korelasyonu arasında; çok yüksek, pozitif yönlü ve anlamlı bir ilişkinin olduğu görülmektedir $(p<.01)$. ANOVA analizi ile değerlendirmecilerin puanlamaları arasında fark olmadığı belirlenmiştir ( $p>$.05). Tüm bu işlemlerin sonunda, ortaokul öğrencilerinin eleştirel düşünme becerilerini değerlendirmeye yönelik geçerli, güvenilir ve kullanılabilir bir ölçme aracı geliştirilmiştir.
\end{abstract}

Anahtar sözcükler: analitik rubrik, değerlendirme, eleştirel düşünme, öyküleyici metin

\section{Evaluation of Critical Thinking Skills in Narrative Texts through a Rubric}

\begin{abstract}
In this study, an analytical rubric was developed to evaluate students' critical thinking skills through narrative texts. The rubric consists of 2 parts and 7 criteria including content comprehension (definition, interpretation) and in-depth comprehension (analysis, deduction, explanation, assumption, evaluation). The study is a qualitative study based on expert opinion. The sample was selected from a middle school students $(n=202)$ with criterion sampling. The content validity of the scale was made by Lawshe technique. The content validity index (CVI) of the content comprehension dimension is 0.89 ; the size of the in-depth comprehension was calculated as 0.87. The reliability of the study is ensured by the "independent evaluator interdependency reliability". As a result of Pearson's correlation analysis, it is seen that there is a very high, positive and significant correlation between the scores average correlations of the evaluators' critical thinking criteria $(p<.01)$. The ANOVA analysis showed that there was no difference between the scores of the evaluators ( $p>$.05). At the end of all these processes, a valid, reliable and usable
\end{abstract}

\footnotetext{
* Bu çalışmada Funda A. İncirkuş’un, Doç. Dr. Latif Beyreli danışmanlığında yürütmüş olduğu doktora tezinin veri analizi için geliştirilen ölçme aracının geçerlik, güvenirlik ve kullanılabilirlik çalışmaları açıklanmıştır.

** Ar. Gör. Dr., Trakya Üniversitesi, Eğitim Fakültesi, Türkçe Eğitimi ABD, Edirne, fundaamanvermez@hotmail.com, ORCID: 0000-0002-5913-122X

*** Doç. Dr., Marmara Üniversitesi, Atatürk Eğitim Fakültesi, Türkçe Eğitimi ABD, İstanbul, beyreli@marmara.edu.tr, ORCID:0000-0002-0130-3332
} 
measuring instrument was developed to evaluate the critical thinking skills of middle school students.

Keywords: analytic rubric, evaluate, critical thinking, narrative text

\section{Giriş}

Çağımızda yaşanan teknoloji tabanlı gelişmeler, bilgi ve bilgiye ulaşma yollarını çeşitlendirmiş; bunun sonucunda üreten, sistematik düşünen, soru soran, anlama ve kavrama becerilerine sahip bireylere ihtiyaç artmıştır. Dolayısıyla, kendisine aktarılan bilgiyi kullanabilen pasif bireyler yerine, bilgiye ulaşma yollarını ve bilgiyi kullanmayı bilen, aktif bireyler yetiştirmek; eğitim sisteminin temel amacı hâline gelmiştir. Bu gelişmeler doğrultusunda ülkemizde 2006, 2017 ve 2018 yıllarında öğretim programlarında değişikliğe gidilmiş ve davranış̧ı yaklaşım terk edilerek öğrenmeyi öğrenen bireyler yetiştirmek hedeflenmiştir. Bu doğrultuda hazırlanan Türkçe dersi öğretim programlarıyla dinlediğini, izlediğini ve okuduğunu anlayan, eleştirel ve yaratıcı düşünen, girişimci; olay, durum ve bilgileri kendi birikimlerinden hareketle yorumlama, sorgulama, araştırma ve eleştirel bir gözle değerlendirmeyi alışkanlık hâline getiren bireyler yetiştirilmesi amaçlanmaktadır (MEB, 2006, s. 3; 2017, s. 3, 10; 2018, s. 3, 8).

Eleştirel düşünme "düşünmeyi geliştirici bir bakış açısıyla analiz etme ve değerlendirme" olarak tanımlanır. Düşünmenin ana unsurları: amaç belirleme, konuyla ilgili soru sorma, bilgi edinme, yorumlama ve çıkarım yapma, kavram oluşturma, varsayımda bulunma, ima etme, önem belirleme ve bakış açısı geliştirmedir (Paul ve Elder, 2006, s. 4-5). Başka bir deyişle bir konuyu farklı yanlarıyla ele alabilme, var olan düşüncelerin yanlışığını gösteren kanıtlara açık olma, akıl yürütme, iddiaları kanıtlarla destekleme, mevcut durumlarla ilgili kararlardan sonuç çıkarma ve bunları anlamaya çalışma, olasılıkları hesaba katma, problem çözme gibi süreçlerden oluşur (Willingham, 2007, s. 8).

1980'lerin sonuna doğru Amerika ve Kanada'daki üniversitelerde beşerî, sosyal, fen ve eğitim bilimleri gibi farklı alanlardan uzmanlar, Amerikan Felsefe Topluluğu adına iki yıl süren bir projeye katılmıştır. Projede amaç, eleştirel düşünme becerilerinin neler olduğu ve bunların nasıl tanımlandığıyla ilgili ortak bir görüş oluşturmaktır. Proje Delfi tekniği uygulanarak gerçekleştiği için "Delfi Projesi" olarak anılmaktadır. Proje sonuçları "Eleştirel Düşünme: Eğitsel Değerlendirme ve Öğretim Amaçlı Uzman Görüşleriyle İlgili Bir Rapor" adıyla yayımlanmıştır. Bugün dünyada ve ülkemizde eleştirel düşünme becerilerini değerlendirmek için kullanılan "California Eleştirel Düşünme Testi (CCTST)" de bu çalışmaya dayanmaktadır. Bu çalışmalardaki ortak görüşe göre eleştirel düşünme becerileri ve tanımları şöyledir (The California Academic Press, 1990, akt. Facione, 2015, s. 9-10): 
Tablo 1. Temel Eleştirel Düşünme Becerileri

\begin{tabular}{|c|c|c|}
\hline Beceriler & Uzman Görüşü Tanımları & Alt Beceriler \\
\hline Yorumlama & $\begin{array}{l}\text { Çok çeşitli deneyimlerin, durumların, verilerin, } \\
\text { olayların, değerlendirmelerin, uzlaşmaların, } \\
\text { kuralların, usullerin veya kriterlerin anlamını veya } \\
\text { önemini kavramak ve ifade etmek. }\end{array}$ & $\begin{array}{l}\text { Sınıflandırma, önemini } \\
\text { kavrama, anlamını açıklama. }\end{array}$ \\
\hline Analiz & $\begin{array}{l}\text { Inançları, değerlendirmeleri, } \\
\text { bilgileri, gerekçeleri, görüşleri ifade etmeyimleri, } \\
\text { amaçlayan açıklamalar, sorular, kavramlar, } \\
\text { tanımlamalar arasındaki çıkarım ilişkilerini } \\
\text { tanımlamak. }\end{array}$ & $\begin{array}{l}\text { Düşünceleri inceleme, konuyu } \\
\text { belirleme, iddiaları ve } \\
\text { sebepleri belirleme. }\end{array}$ \\
\hline Çıkarım & $\begin{array}{l}\text { Mantıklı sonuç çıkarmak için gerekli olan unsurları } \\
\text { belirlemek ve güvence altına almak; hipotezler ve } \\
\text { varsayımlar oluşturmak; verilerden, ifadelerden, } \\
\text { ilkelerden, kanıtlardan, değerlendirmelerden, } \\
\text { inançlardan, düşüncelerden, kavramlardan, } \\
\text { tanımlardan, sorulardan ve diğer temsil } \\
\text { biçimlerinden gelen sonuçları özetlemek ve } \\
\text { bunlarla ilgili bilgileri dikkate almak. }\end{array}$ & $\begin{array}{l}\text { ífadeleri sorgulama, } \\
\text { varsayımları tahmin etme, } \\
\text { mantıksal olarak geçerli veya } \\
\text { doğru sonuç çıkarma. }\end{array}$ \\
\hline Değerlendirme & $\begin{array}{l}\text { Bir kişinin algısını, deneyimlerini, ifadelerini, } \\
\text { kararlarını, inançlarını, düşüncelerini ya da diğer } \\
\text { temsil biçimlerini tanımlayan ya da açıklayan } \\
\text { ifadelerin güvenirliğini belirlemek; açıklamalar, } \\
\text { tanımlar, sorular veya diğer temsil şekilleri } \\
\text { arasındaki ilişkilerin mantıksal gücünü } \\
\text { değerlendirmek. }\end{array}$ & $\begin{array}{l}\text { İddiaların güvenilirliğini } \\
\text { değerlendirme, tümevarım ya } \\
\text { da tümdengelim yöntemiyle } \\
\text { konuyla ilgili tartışmaların } \\
\text { kalitesini değerlendirme. }\end{array}$ \\
\hline Açıklama & $\begin{array}{l}\text { Bir kişinin gerekçelerinin kaynağını oluşturan } \\
\text { bağlamsal, yöntemle ilgili, kavramsal, kanıtlayıcı } \\
\text { ve kritik hususları savunmak ve belirtmek. }\end{array}$ & $\begin{array}{l}\text { Sonuçları belirtme, yapılan } \\
\text { şeyleri savunma, görüş sunma. }\end{array}$ \\
\hline Öz-düzenleme & $\begin{array}{l}\text { Kendi bilişsel süreçlerini, bu süreçte yaptıklarını } \\
\text { ve bunların sonuçlarını bilinçli bir şekilde izlemek; } \\
\text { özellikle analiz ve değerlendirme becerilerini } \\
\text { kullanarak kişinin kendi çıkarımlarını ve } \\
\text { değerlendirmelerini sorgulamak, doğrulamak, } \\
\text { onaylamak ya da düzeltmek. }\end{array}$ & $\begin{array}{l}\text { Kendini izleme, kendini } \\
\text { düzeltme. }\end{array}$ \\
\hline
\end{tabular}

Bugünün öğrencilerinden beklenen, öğrenmeyi öğrenen ve öğrendiklerini gerekçeleriyle birlikte düşünebilen bireyler olmalarıdır. Öğrenciler edindikleri bilgiler arasında mantıksal ilişkiler kurabilmeli, anlamı yapılandırmalı, farkıı görüşlere açık olmalı ve gerektiğinde düşüncelerini yeniden düzenleyecek esnekliğe sahip olabilmelidir. İşte, bunların hepsi eleştirel düşünmeyi gerektirmektedir. Bundan dolayı eleştirel düşünme farklı disiplinlere yönelik ortak bir hedeftir (MacKnight, 2000, s. 38).

Eleştirel düşünme öğretiminde önemli hususlardan biri öğrencilere nasıl düşünmeleri gerektiğini öğretebilmektir. Bunun yanında öğrencilerin konuyla ilgili ön bilgilerini oluşturmak ve uygulama yaptırmak da önemlidir (Willingham, 2007, s. 8-9; Schmit, 2002, s. 104). Bu bakımdan öğretmenler, sınıf içi uygulamalarla öğrencileri destekleyerek onların bağımsız bir şekilde eleştirel düşünmesine yardımcı olmalıdır. Eleştirel düşünme, bağlamdan kopuk olarak gerçekleşmez; üzerine düşünülecek bir konunun olması ve bu konuyu derinlemesine incelemeye olanak verecek bilgi 
birikiminin bulunması gerekir. Bu bakımdan öğretmenler öğrencilere, konuyla ilgili bir temel oluşturacak eğitimi vermelidir. Bu yaklaşımların ortak özelliği eleştirel düşünmenin öğretilebilen ve öğrenilebilen bir beceri olduğudur. Öğrenciler bu becerileri doğru bir şekilde öğrenip uyguladığında iyi bir "eleştirel düşünür" olurlar (Halpern, 1999, s. 70).

Eleştirel düşünürler okudukları ya da duydukları bir bilgiyi/düşünceyi doğrudan kabul etmek yerine bunlara inanmak için geçerli bir sebep ya da kanıt ararlar. Herhangi bir konuda ya da disiplinde eleştirel düşünme; teorinin, geliştirilen yöntem ve tekniklerle özel durumlara uygulanabilmesidir. Bu da sistemli bir biçimde soru sormayı ve soruları cevaplamayı gerektirir (Learning Development, 2010, s. 4).

King $(1995$, s. 13) tarafından geliştirilen sorgulama tabanlı öğrenme modeline göre öğrencilerin eleştirel bir düşünür hâline gelebilmeleri için sorgulayıcı bir zihne sahip olmaları gerekmektedir. Buna göre öğretmenler öğrencilere doğru soruları sormayı öğretebilirse kendi düşünme-öğrenme süreçlerinin sorumluluğunu almayı da kazandırabilir. Öğretmen öğrencilerin bilgilerini, çıkarımlarını, tahminlerini vb. bilgileri ortaya çıkarmak için onlara yönlendirici sorular sorar. Öğrenciler sınıf tartışmalarında ve sınıftaki bağımsız çalışmalarda ya da evde kendi başına çalışırken de bu sorulardan yararlanarak bu becerileri kazanırlar. Sorgulama tabanlı öğrenmenin önemli özelliklerinden biri, öğrencilerin sadece doğru cevabı bulmaya odaklanmamasıdır. Bu modelde öğrenciler, anlamaya ilişkin eksikliklerine, bilgi boşluklarına ya da belli bir konudaki yanlış anlamalarına yönelik sorular sorup cevaplarlar; böylece kendi öğrenmelerine uygun sorgulama ve cevaplamalarla kavramlar arasındaki ilişkileri kalıcı olarak zihinlerine yerleştirebilirler. Bu modelde belirlenen eleştirel düşünme becerileri ve bu becerilere yönelik genel soru tipleri şöyledir (King, 1995, s. 14):

Tablo 2. Eleştirel Düşünmeye Yönelik Sorular

\begin{tabular}{l|l}
\hline Etkilediği Düşünme Becerileri & Genel Sorular \\
\hline 1. Analiz (ilişki analizi): & $\ldots$, ...yı nasıl etkilemiştir? \\
\hline 2. Analiz (önem analizi): & $\ldots$ niçin önemli? \\
\hline 3. Analiz (sebep-sonuç analizi): & ...nın sebepleri neler? Niçin? \\
\hline 4. Analiz/çıkarım yapma: & ...dan çıkarılacak şey nedir? / ... ile ima edilen şey nedir? \\
\hline 5. Analiz/çıkarım yapma: & ...nın güçlü ve zayıf yanları neler? \\
\hline 6. Analiz/çıkarım yapma: & $\ldots$ niçin oldu / ... niçin meydana geldi? \\
\hline 7. Analiz: & $\ldots$ ne demek? \\
\hline 8. Analiz: & ...nın yapısı nasıldır? \\
\hline 9. Analiz: & ...nın niçin olduğunu açıklayın. / ... nasıl olduğunu açıklayın. \\
\hline 10. Bakış açısı geliştirme: & $\ldots$ ya farklı bir açıdan bakmanın başka yolu nedir? \\
\hline 11. Belirleme (metaforlar ve analojiler) & $\ldots$ neye benziyor? \\
\hline
\end{tabular}




\begin{tabular}{|c|c|}
\hline $\begin{array}{l}\text { 12. Değerlendirme ve ipuçlarını } \\
\text { kullanma: }\end{array}$ & ... için en iyi ne olurdu? Neden? \\
\hline $\begin{array}{l}\text { 13. Değerlendirme ve ipuçlarını } \\
\text { kullanma: }\end{array}$ & ...ya katıldığınız/katılmadığınız yerler neler? \\
\hline $\begin{array}{l}\text { 14. Değerlendirme ve ipuçlarını } \\
\text { kullanma: }\end{array}$ & Cevabınızı destekleyecek ipuçları nelerdir? \\
\hline 15. Gerçek dünyaya uyarlama: & Bu durum gerçek dünyaya nasıl uyarlanır? \\
\hline $\begin{array}{l}\text { 16. Hipotez-varsayımda bulunma / } \\
\text { tahmin: }\end{array}$ & ... olsaydı ne olurdu? \\
\hline 17. Karşı görüş geliştirme: & ...ya karşı görüş ne olabilir? / ... nasıl çürütülür? \\
\hline 18. Karşılaştırma: & ...yı ... ile ilişkilendirerek karşılaştırın. \\
\hline 19. Karşılaştırma (zıtlıklar): & ... ile ... arasındaki farklılıklar neler? \\
\hline 20. Karşılaştırma (benzerlikler): & ... ile ... arasındaki benzerlikler neler? \\
\hline 21. Önceki bilgiyi harekete geçirme: & Bu konu hakkında daha önce bildikleriniz neler? \\
\hline 22. Önceki bilgiyi harekete geçirme: & ... ile önceki bilgilerin arasında nasıl bir bağlantı var? \\
\hline 23. Sentez (düşünceleri birleştirme): & ... problemi için nasıl bir çözüm olabilir? \\
\hline 24. Uygulama: & ..., ...da nasıl kullanılabilir? \\
\hline 25. Uygulama: & ...ya farklı bir örnek ne olabilir? \\
\hline
\end{tabular}

Uzmanların ortak görüşüyle belirlenen (yukarıda açıklanan) becerilere dayalı olarak hazırlanan “Kaliforniya Eleştirel Düşünme Becerileri Testi”nde (CCTST) eleştirel düşünme becerilerini harekete geçirecek soru örnekleri şöyledir (Facione, 2015, s. 8):

Eleştirel Düşünme Becerilerini Harekete Geçirecek Sorular

Bu ne anlama geliyor? Ne oluyor?, Bunu nasıl anlayabiliriz? (birinin söylediği bir şeyi), Bunu sınıflandırmanın/nitelemenin en iyi yolu nedir? Bu bağlamda bunu söyleyerek/yaparak neyi amaçladınız? Bunu nasıl anlamlı hâle Yorumlama getirebiliriz? (deneyimleri, duyguları ya da ifadeleri)

Analiz Bu iddiayı ortaya koymanızı sağlayan nedenleri söyleyin.

Bu konuda ulaştığınız sonuç/iddia ettiğiniz şey nedir? Neden öyle düşünüyorsunuz? Bu sonucu kabul etmek için hangi varsayımlardan yola çıkmalıyız? Bunu söylerken dayandığınız temeller nelerdir?

Konunun lehinde ve aleyhinde olan şeyler nelerdir?

Çıkarım Şimdiye kadarki bilgilerimizle hangi sonuca ulaşırız?

Şimdiye kadarki bilgilerimizle neleri eleyebiliriz?

$\mathrm{Bu}$ kanıt bize neyi gösterir? Eğer bu varsayımı kabul etseydik ya da etmeseydik işler nasıl değişirdi? Bunu bu şekilde yapmanın sonuçları nelerdir?

Değerlendirme doğru?

Bu iddia ne kadar inandırıcı/güçlü? Var olan bilgilerimiz doğru mu/ne kadar

Bu kişinin iddialarına neden güvenebiliriz? 


\begin{tabular}{ll}
\hline Açıklama & Bu incelemeden elde edilen bulgular/sonuçlar nelerdir? \\
& Bu analizi nasıl yaptığınızı anlatın. \\
& Bu konudaki gerekçelerinizi bir kez daha açıklayın. \\
& Neden böyle düşünüyorsunuz? (Doğru cevap ya da doğru çözüm olduğu için mi?) \\
& Bu kararı neden verdiğinizi ayrıntılarıyla açıklayabilir misiniz? \\
& $\begin{array}{l}\text { Bu konudaki görüşünüz hâlâ belirsiz, daha açık olabilir misiniz?, Yönteminiz ne } \\
\text { kadar iyiydi bunu ne kadar devam ettirebildiniz?, Görünüşte çelişkili olan iki } \\
\text { sonucun uzlaştırılmasının bir yolu var mı?, Kanıtlarınız ne kadar iyi? Önermede } \\
\text { bulunmadan önce kaçırdığınız bir şeyler var mı? Bazı tanımlarınızı kafa karıştırıcı } \\
\text { buluyorum, son kararı vermeden önce bununla ne kast ettiğinizi gözden geçirebilir } \\
\text { misiniz? }\end{array}$ \\
Öz-düzenleme
\end{tabular}

Plymouth Üniversitesi tarafından öğrencilerin eleştirel düşünmesine yardımcı olacak doğrusal bir model oluşturulmuştur. Bu modelde diğerlerinden farklı olarak "tanımlama" becerisine yer verilmiştir, çünkü eleştirel düşünme bağlamdan bağımsız olarak gerçekleşmez. Öğrenciler ne hakkında konuştuklarını, bunun neleri içerdiğini, nerede olduğunu ya da hangi şartlar altında gerçekleştiğini açıkça tanımlayabilmelidir. Tanımlama becerisi öğrencinin yeni bir konuya giriş yapabilmesi ya da konuyla ilgili bilgilerini hatırlaması bakımından önemlidir. Tanımlamalar karmaşıklaştıkça analiz hâline gelecektir. Bu modelde yer verilen eleştirel düşünme becerileri ve tavsiye edilen sorular şöyledir (Learning Development, 2010, s. 4):

Tablo 3. Eleştirel Düşünme-Doğrusal Bir Model

\begin{tabular}{|c|c|}
\hline Beceriler & Sorular \\
\hline $\begin{array}{l}\text { Tanımlama: Konuyu belirleme, } \\
\text { tanıtma ve problemi/konuyu } \\
\text { önceki bilgilerle birlikte ele } \\
\text { alma. }\end{array}$ & $\begin{array}{l}\text { Ne/Hangi? } \\
\text { Ne hakkında?, Konu/durum ne?, Bulunan ana nokta/problem/başlık } \\
\text { nedir? } \\
\text { Nerede? } \\
\text { Nerede bulunuyor? } \\
\text { Kim? } \\
\text { Kim tarafından?, Kiminle ilgili/işin içinde kimler var?, Etkilenen kim?, } \\
\text { Kimleri ilgilendiriyor olabilir? } \\
\text { Ne zaman? } \\
\text { Bu, ne zaman meydana gelir? }\end{array}$ \\
\hline $\begin{array}{l}\text { Analiz: Parçayla bütün } \\
\text { arasındaki ilişkiyi bulma, } \\
\text { parçaların bir bütün hâlinde } \\
\text { nasıl ele alındığını açıklama ve } \\
\text { değerlendirme, gerekçe sunma, } \\
\text { farklı ögeleri karşılaştırma, } \\
\text { zıtlıkları bulma, olası durumlara } \\
\text { çözüm bulma, ilişkileri nasıl } \\
\text { anladığını gösterme. }\end{array}$ & $\begin{array}{l}\text { Nasıl? } \\
\text { Bu nasıl meydana geldi?, Bu teoride veya uygulamada/bağlamda } \\
\text { nasıl çalışır? } \\
\text { Bir unsur diğer bir unsuru nasıl etkiler?, Bu parçalardan nasıl bütüne } \\
\text { ulaşılır? } \\
\text { Niçin? } \\
\text { Bu niçin oluştu?, Bu niçin yapıldı? } \\
\text { Neden bu görüşü, öneriyi, çözümü, teoriyi söylüyorsun?, Neden } \\
\text { başka bir şey değil de bu? } \\
\text { Eğer...? }\end{array}$ \\
\hline
\end{tabular}




\begin{tabular}{|c|c|}
\hline & $\begin{array}{l}\text { Bu yanlış olsaydı ne olurdu?, Bu konudaki alternatifler neler?, Bir } \\
\text { problem ortaya çıksaydı ne olurdu?, Bu unsur } \\
\text { kaldırılsa/eklense/değiştirilse ne olurdu? }\end{array}$ \\
\hline 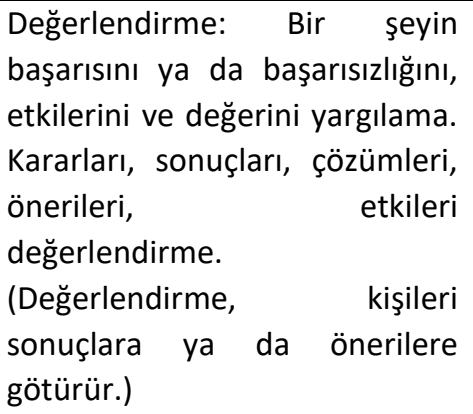 & $\begin{array}{l}\text { Yani? } \\
\text { Bu ne anlama gelir?, Bu niçin önemli? } \\
\text { Bu inandırıcı mı? Niçin inandırıcı/niçin değil?, Çıkarılan sonuçlar } \\
\text { neler? } \\
\text { Başarılı mı?, Kriterleri nasıl karşılar? } \\
\text { Sırada ne var? } \\
\text { Transfer edilebilir mi?, Nerede ve nasıl uygulanabilir?, Ondan ne } \\
\text { öğrenilebilir? } \\
\text { Şu anda ne yapmak gerekiyor? }\end{array}$ \\
\hline
\end{tabular}

Herhangi bir konuda ya da disiplinde eleştirel düşünme, teorinin, geliştirilen yöntem ve tekniklerle özel durumlara uygulanabilmesidir. Bu bakımdan eleştirel düşünme becerileri farklı çalışmalarda farklı yönlerden ele alınmıştır. Bu çalışmada uzman görüşleri doğrultusunda öğrencilerin içerik bilgisine sahip olarak derinlemesine düşünmesini sağlayacak eleştirel düşünme becerileri; tanımlama, yorumlama, analiz, çıkarım, açıklama, varsayımda bulunma ve değerlendirme olarak belirlenmiştir (bkz. Tablo 5).

\section{Rubrik (Dereceli Puanlama Anahtarı) Türleri}

Dereceli puanlama anahtarları, öğrenci çalışmalarının önceden belirlenen performans kriterlerine göre değerlendirilmesini sağlayan puanlama rehberleri olarak tanımlanmaktadır (Mertler, 2001, s. 1). Başka bir ifadeyle dereceli puanlama anahtarlarının, bir performansı ya da ödevi değerlendirirken parçalarına ayıran ve her parça için beklenen (kabul edilebilir ve kabul edilemez) performans düzeylerini açıkça belirten değerlendirme araçları olduğu söylenebilir. Dereceli puanlama anahtarları, öğrenme sürecinde öğrencinin gelişimiyle ilgili geri bildirim yapmak, öğrencileri düzeylere ayırmak ya da uygulanan programı değerlendirmek için de kullanılabilir (Allen, 2014, s. 1; MEB, 2017, S. 8).

Dereceli puanlama anahtarları genellikle "bütüncül ve analitik" olmak üzere iki türe ayrılır. Bütüncül puanlama anahtarları, öğretmenin tüm süreci veya ürünü bir bütün olarak, parçaları ayrı ayrı değerlendirmeden puanlamasını gerektirir (Nitko, 2001, akt. Mertler, 2001, s. 1). Analitik puanlama anahtarları ise, bir performansla ilgili birden fazla sonucun aynı anda değerlendirildiği ya da çok boyutlu ürünlerde her bir boyutun ayrı ayrı derecelendirilmesinin gerektiği durumlarda kullanılır (Moskal, 2000, s. 3). Yani analitik puanlama anahtarları, önce performans veya ürünün parçalarının ayrı ayrı puanlanmasını, sonra bu puanların toplanarak toplam puanın hesaplanmasını gerektirir (Bahar vd., 2014, s. 51). 
Analitik puanlama anahtarları her bir kriter için yapılan değerlendirmeyi açıklamaktadır. Bu yönüyle bütüncül puanlama anahtarlarına göre daha kullanışlıdır çünkü her seviyedeki performans düzeyini detaylı açıklar, öğrencilerin zayıf ve kuvvetli yanlarını belirlemelerine yardımcı olarak düşük performans sergilediği alandaki eksikliklerini fark etmesini sağlar. Böylelikle öğrenci, hedeflenen öğretim amaçlarının, değerlendirme kriterlerinin farkında olarak kendisinden beklenen performans hakkında bilgi sahibi olur. Bu bakımdan analitik puanlama anahtarları öz değerlendirme formu gibi de kullanılabilir.

\section{Araştırmanın Amacı ve Önemi}

Türkçe Dersi Öğretim Programı'nda (2018, s. 8-9) 4-8. sınıflarda süreç değerlendirme kadar sonuç değerlendirmenin de önemli olduğu belirtilmiştir. Bu sınıf düzeylerinde yazılı sınavlardan yararlanılması gerektiği ve bu sınavlar oluşturulurken öğretim programındaki kazanımlara paralel olarak öğrencilerin üst düzey düşünme becerilerini harekete geçirecek maddeler hazırlanması gerektiği vurgulanmıştır. Bu maddeler aracılığı ile öğrencilerin çıkarım yapma, analiz etme, akıl yürütme, görsel ve uzamsal zekâlarını kullanma ve eleştirel düşünme becerilerini geliştirmeleri amaçlanmaktadır. Hazırlanan soruların; eski ve yeni bilgilerin birleştirilmesini, diğer disiplinlerle ve günlük hayatla ilişki kurulmasını sağlayacak şekilde yapılandırılması gerektiği ifade edilmiştir. Gerçek hayatla ilişkili soruların, öğrencilerin çıkarım yapma ve öğrendikleri bilgileri nerede, nasıl kullanacaklarına yönelik farkındalıklarını artıracağı düşünülmektedir. Bununla birlikte dil becerilerinin bütüncül ve/veya ayrı ayrı değerlendirilmesi gerektiği de dile getirilmektedir.

Okuma becerisi öğrenme, araştırma, yorumlama, tartışma ve eleştirel düşünme gibi bir dizi süreci içine almaktadır. Türkçe Dersi Öğretim Programlarında $(2006,2017,2018)$ ve Ortaokul ve İmam Hatip Ortaokulu Okuma Becerileri Dersi Öğretim Programı́nda (2012) okuma eğitimi bağlamında, okuduğunu anlama becerisi kazandırmak kadar eleştirel düşünme becerisi kazandırmanın da gerekliliği üzerinde durulmuştur; çünkü okuma sürecinin tam olarak gerçekleşmesi, okunanların değerlendirilmesiyle mümkündür. Öğrencinin değerlendirme yapabilmesi ise okunanlar üzerine eleştirel bir bakış açısıyla düşünebilmesini gerektirir. Ortaokullar ve İmam Hatip Ortaokulları İçin Hazırlanan Okuma Becerileri Programı'nda (2012, s. 4) okuma; “anlama, yorumlama, çözümleme gibi farklı zihinsel işlemlerin bir arada gerçekleştiği; öğrenme ve eleştirel düşünme bilincinin gelişmesinde en etkili dil becerisi" olarak tanımlanmıştır. Başka bir deyişle eleştirel düşünmenin gerçekleşebilmesi için konuyla ilgili içerik bilgisine sahip olmak gerekir ki bu da genellikle okuma yoluyla mümkün olmaktadır.

Öğrencilerin anlama düzeylerini belirlemede en önemli araçlardan biri "soru"dur. Sorular, anlama becerilerinin geliştirilmesinde hem bir öğretim hem de bir değerlendirme aracı olarak 
görülmekte ve kullanılmaktadır (Akyol vd., 2014, s. 90; Akyol, 2014, s. 100). Öğretmenler, öğrencilerin okuduğunu anlama ve okuma sürecine eleştirel bir gözle bakmalarını sağlayacak üst düzey düşünme becerilerini harekete geçirmelidir. Bunun için anlamayı değerlendirmede hem metnin içeriğini anlamaya yönelik okuduğunu anlama soruları hem de metni farklı yönlerden ele alarak derinlemesine anlamayı sağlayan eleştirel düşünme soruları sorulmalıdır. Okuma metinleri, eleştirel düşünmenin öğrenilmesi ve öğretilmesini sağlayan güçlü bir bağlamdır. Norris ve Philips'e (1987) göre eleştirel okumanın özü, okunan metne alternatif yorumlar getirebilmektir. Onlara göre edebî düşünce; fikirleri analiz etme, sentezleme, yeniden düzenleme, bağlantı kurma ve düşünceleri genelleştirme gibi karmaşık bir akıl yürütme sürecidir. Bundan dolayı okumayı değerlendirme, öğrencinin verdiği cevaplarla öğretmenin cevaplarının örtüştüğü basit bir değerlendirme değildir. Günümüzde okumayı değerlendirme, öğrencinin konuyla ilgili görüşlerinin ve gerekçelerinin kalitesi de kapsayan çok yönlü bir süreçtir.

Kapsamlı ve çok yönlü bir değerlendirmenin en etkili yollarından biri öğrencilere konuyla ilgili açık uçlu sorular sormaktır. Açık uçlu sorular-kısa cevaplı ve çoktan seçmeli soruların aksine- öğrencinin görevle ilgili kendi cevabını oluşturmasını sağlayarak düşünme ve anlama sürecini geliştirir. Geniş kapsamlı değerlendirme süreçlerinde açık uçlu sorularla ilgili elde edilen bilgiler, her ne kadar zaman alııı ve masrafı olsa da bu tip soruların değerlendirme sürecinde kullanılması gerekliliği vurgulanmaktadır (Badger ve Thomas, 1992, s. 2-3).

Türkçe Dersi Öğretim Programıyla okuduğunu anlayabilen ve okuduklarını eleştirel bir bakış açısıyla değerlendirip yorumlayabilen bireyler yetiştirmek amaçlanmıştır (MEB, 2006, s. 6; 2017, s. 10; 2018, s. 3, 5). Yukarıda değinildiği üzere bunun en etkili yollarından biri öğrencilere açık uçlu sorular sormaktır. Programın ölçme ve değerlendirmeyle ilgili açıklamalarında, açık uçlu soruların, öğrencilerin başarılarını ölçmek için kullanıldığı ve öğrencilerin düşüncelerini ayrıntılı olarak incelemeye imkân verdiği belirtilmiştir. Ancak bu olumlu yanlarına rağmen açık uçlu sorulara dayalı değerlendirmede; cevaplamanın ve puanlamanın zaman almasından, cevapların tamamen doğru ya da tamamen yanlış olarak sınıflandırılamamasından, dolayısıyla cevapların doğruluk derecesinin belirlenmesinin puanlayıcıya düşmesinden ve puanlamada objektifliğin sağlanamamasından dolayı bazı sınırılıkların olduğu da dikkate alınmalıdır (MEB, 2006, s. 219). Ancak böyle bir yaklaşım, açık uçlu soruların kullanım amacıyla çelişmektedir. Öncelikle açık uçlu sorular, cevapları belli olan sorulardan çok daha fazlasını ifade eder. Açık uçlu sorular, öğrencilerin konuyla ilgili bilgi ve becerilerini ortaya koyan ürünler ya da cevaplar oluşturmasını sağlayarak öğrencilerin düşünme becerilerini geliştirmek için kullanılmalıdır. Bu yüzden açık uçlu sorularda tamamen doğru veya tamamen yanlış cevaplar aramaktansa, öğrencilerin konuyla ilgili açıklamalarının ve gerekçelendirmelerinin kalitesi dikkate alınmalıdır. Yani öğretmen açık uçlu sorular aracılığıyla öğrencinin bilgiyi nasıl anladığını ve onu nasıl kullandığını değerlendirmelidir. 
Burada puanlayıcının/öğretmenin objektifliğini sağlamak için de amaca uygun dereceli puanlama anahtarlarından yararlanarak puanlamada oluşabilecek hatalar ortadan kaldırılabilir.

Öğretim programları incelendiğinde yaratıcı düşünme, iletişim kurma, problem çözme, karar verme, eleştirel düşünme gibi temel becerilere, dil becerilerinin geliştirilmesinde ve değerlendirilmesinde birçok yerde vurgu yapıldığı görülmektedir (MEB, 2006, s. 3, 4, 5, 6, 56; 2017, s. 10; 2018, s. 3, 5, 8, 10). 2006 tarihli İlköğretim Türkçe Dersi Öğretim Programı'nda (2006, s. 228-242) konuşma, dinleme, yazma ve okuma alanlarına yönelik değerlendirme ve gözlem formları yer almasına rağmen; öğretimin bütün aşamalarında geliştirilmesi beklenen eleştirel düşünmeyle ilgili bir değerlendirme formu bulunmamaktadır. 2018 yılında hazırlanan programda da konuyla ilgili örnek bir form yer almamaktadır. Oysa yurtdışındaki çalışmalara ve öğretim programlarına bakıldığında ilk seviyeden üniversiteye kadar farklı düzeylerde ürün ve davranışları değerlendirmek için okuduğunu anlama, konuşma/sözlü sunum, yazma ve eleştirel düşünmeye yönelik analitik puanlama anahtarlarının kullanıldığı görülmektedir (CFSD, 2015; Allen, 2014; Center for Teaching, 2006; Peirce, 2006).

Bu çalışmada öğrencilerin Türkçe derslerinde okudukları bir metnin içeriğini anlamaları ve metnin konusu üzerine derinlemesine düşünmelerini sağlamak amacıyla belirli performans kriterlerinde açık uçlu sorular hazırlanarak öğrencilerin eleştirel düşünme becerilerinin geliştirilmesine yönelik uygulamalar yapılmıştır. Yapılan bu uygulamaları değerlendirmek amacıyla öyküleyici metinlerde kullanılmak üzere iki boyuttan (içeriği anlama ve derinlemesine bakış) oluşan analitik (çözümleyici) bir eleştirel düşünme rubriği hazırlanarak kullanılabilirliği denenmiştir. Böylelikle Türkçe derslerinde öyküleyici metinler aracılığıyla eleştirel düşünme becerilerinin değerlendirilmesinde kullanılacak soru tiplerinin belirlenmesi, performansa dayalı değerlendirme kriterlerinin, yeterlik düzeylerinin nasıl olması gerektiği ve kriter düzeylerinin nasıl tanımlanabileceği ortaya konmuştur.

\section{Yöntem}

Çalışmada, aday ölçek formundaki maddelere/kriterlere ve ölçeğin bölümlerine ilişkin uzman görüşü alınarak nitel yöntemden faydalanılmıştır. Kapsam geçerlik oranları ve uzman görüşleri arasındaki uyum çalışmasıyla nitel süreç nicel yolla desteklenmiştir. Çalışma iki aşamada gerçekleşmiştir.

Birinci aşamada doküman incelemesi yapılarak ilgili literatür taranmış ve Türkçe derslerinde eleştirel düşünme becerisi için ölçülebilecek kriterler, kriter ölçütleri ve bu kriterleri karşıllayan soru tipleri uzman görüşüne dayalı olarak belirlenmeye çalışımıştır (bkz tablo 5). Bilindiği üzere doküman incelemesi araştırılması hedeflenen olgu veya olgular hakkında bilgi içeren yazılı materyallerin analizini kapsamaktadır (Yıldırım ve Şimşek, 2013, s. 217) 
İkinci aşamada, hazırlanan ölçme aracının güvenirliğini belirlemek için tarama modeli uygulanmıştır. Tarama modellerinde çok sayıda örnek üzerinde çalışma olanağı ve zorunluluğu bulunduğundan kesit alma yolu ile elde edilen verilerin genellenebilirliği sağlanır. İlişkisel tarama modelleri iki ve daha çok sayıdaki değişken arasında birlikte değişim varlığını ve/veya derecesini belirlemeyi amaçlayan araştırma modelleridir. Iliş̧kisel çözümleme korelasyon ve karşılaştırma yolu ile sağlanır (Karasar, 2012, s. 77, 80, 81). Araştırmada hazırlanan rubriğin güvenirliğini artırmak için ortaokul seviyesinde her sınıf düzeyinden öğrencinin yer aldığı büyük bir grupla çalışıımıştır. Bu amaçla hazırlanan rubrik: Ataşehir (İstanbul), Pendik (İstanbul), Gebze (Kocaeli), Yıldırım (Bursa) ve Kemer (Antalya) ilçelerindeki ortaokullara devam eden 5, 6, 7 ve 8. sınıftan 652 öğrenciye uygulanmıştır. Elde edilen veriler araştırmanın çalışma grubunu oluşturmuştur. Bu verilerden rastgele (5. sınıflarda 50, 6 . sınıflarda 52, 7. sınıflarda 50 ve 8. sınıflarda 50) 202 kâğıt seçilmiş ve 4 değerlendirmeci tarafından değerlendirilmiştir

\section{Çalışma Grubu}

Çalışma grubu, amaçlı örnekleme yöntemlerinden ölçüt örnekleme ile belirlenmiştir. Ölçüt örnekleme yaklaşımında amaç çalışma grubunun araştırmacı tarafından belirlenen ölçütlere uygun olmasıdır (Yıldırım ve Şimşek, 2013, s. 140). Eleştirel düşünme her sınıf düzeyinde kazandırılması gereken bir beceri olmakla birlikte temelde "analiz, değerlendirme ve akıl yürütme" gibi karmaşık bilişsel süreçlere dayanmaktadır. Bilişsel gelişim kuramına göre bireyler, ilköğretim ikinci kademe döneminde yani 11 yaş sonrasında soyut fikirlere ilişkin akıl yürütebilirler (Küçükkaragöz, 2014, s. 100). Bu bakımdan veri toplama sürecinde ortaokul öğrencileri $(5,6,7$ ve 8 . sınıflar) çalışma grubuna dâhil edilmiştir.

Rubriğin geliştirilme sürecinde;

- Pilot uygulama, 40 ortaokul öğrencisi ve 6 Türkçe öğretmeniyle,

- Rubriğin kapsam geçerliği, 5 alan uzmanı (4 Türkçe eğitimi, 1 Ölçme-Değerlendirme) ve 4 Türkçe öğretmeniyle

- Güvenirlik için değerlendirmeciler arası uyum çalışması, 4 Türkçe öğretmeni ile çalışılmıştır.

Değerlendirmecilere ilişkin bilgiler şöyledir:

1. değerlendirmeci: Erkek, yüksek lisans mezunu, 11 yıllık mesleki deneyime sahip ve devlet okulunda Türkçe Öğretmeni olarak çalışmaktadır.

2. değerlendirmeci: Erkek, yüksek lisans mezunu, 8 yıllık mesleki deneyime sahip ve devlet okulunda Türkçe Öğretmeni olarak çalışmaktadır. 
3. değerlendirmeci: Kadın, yüksek lisans mezunu, 12 yıllık mesleki deneyime sahip ve devlet okulunda Türkçe Öğretmeni olarak çalışmaktadır.

4. değerlendirmeci: Kadın, lisans mezunu, 8 yıllık mesleki deneyime sahip ve devlet okulunda Türkçe Öğretmeni olarak çalışmaktadır.

\section{Veri Toplama Araçları}

Araştırmanın veri toplama aracı "Öyküleyici Metinler İçin Analitik Eleştirel Düşünme Rubriği"dir. Bu rubriğin geçerlik ve güvenirlik çalışmalarında kullanılmak üzere rubrik kriterlerini karşılayan örnek bir metin belirlenmiş ve bu metne bağlı kriterleri karşılayan sorulara öğrencilerin yazııı olarak verdiği cevaplar da veri toplama aracı olarak kullanılmıştır. Rubrik kendi içinde "tanımlama, yorumlama, analiz, çıkarım, açıklama, varsayımda bulunma ve değerlendirme" olmak üzere yedi kriterden oluşmaktadır. Bu kriterlerden tanımlama ve yorumlama kriterinde sorulara verilen cevaplar metnin içeriğini anlamaya; analiz, çıkarım, açıklama, varsayımda bulunma ve değerlendirme kriterindeki sorulara verilen cevaplar ise metni derinlemesine anlamaya yönelik olarak hazırlanmıştır. Çalışmada kullanılan metin(ler) uzman görüşüyle belirlenmiştir. Bunun için 26 metin, akademisyen ve öğretmenlerden oluşan 19 kişi tarafından değerlendirilmiş ve rubrik kriterlerini içerdiği düşünülen metinlerden 1 tanesi rubriğin kullanılabilirliğini göstermek üzere örnek olarak belirlenmiştir. Seçilen metinle ilgili tespit edilen kriterlerin değerlendirilmesi için önceden hazırlanan soru tiplerinden (EK-1) yararlanılarak 22 tane açık uçlu okuma sonrası sorusu oluşturulmuştur. Lawshe tekniğiyle belirlenen uzman ( $N=9)$ görüşleri doğrultusunda içeriği anlamayla ilgili 7 ( $K G i=0,87)$, derinlemesine anlamayla ilgili $5(K G i=0,83)$ tane açık uçlu örnek soru kullanılmıştır.

\section{Veri Toplama Aracının Geliştirilmesi}

Ölçek geliştirme çalışmalarında ilk olarak ulusal ve uluslararası düzeyde benzer ölçek çalışmaları taranmıştır. Bu kapsamda, Catalina Foothills School District, South Washington Country Schools, Medford Public Schools, Belingham Public Schools gibi okulların eleştirel düşünme ile ilgili hazırladıkları ölçekler incelenmiştir. Bunun yanında ABD'de Association of American Colleges and Universities adıyla farklı üniversite ve kolejlerin öğretmen ve öğretim üyelerinden oluşan bir komisyon tarafından farklı üniversitelerin rubriklerinin incelendiği ve her alandan lisans öğrencilerinin sahip olması gereken genel becerileri ortak bir standarta göre değerlendirmek için hazırlanan eleştirel düşünme becerilerine yönelik rubrikler incelenmiştir. Gerek bu rubrikler gerekse ABD'deki birçok üniversite tarafından kullanılan "Value Rubric" örnekleri de incelenmiştir.

Alandaki hemen hemen bütün örnekler incelendikten sonra çalışmaya uygun olarak ölçeğin amacı, kriterleri, düzeyleri ve tanımları belirlenmiştir. Analitik eleştirel düşünme rubriği geliştirme 
aşamaları şöyledir (Mertler, 2001, s. 4.; Roberts, 2008, s. 24; Hawaii, 2012, akt. Brophy, e.t. 25.06.2018, s. 5-6):

1. Amaç belirleme,

2. Değerlendirme kriterlerinin belirlenmesi,

3. Kriterler için yeterlik düzeylerinin belirlenmesi,

4. Her bir kriter için düzeylerin tanımlanması (Öncelikle en yüksek ve en düşük performans düzeylerinin, daha sonra ara düzeylerin tanımlanması),

5. Rubriği deneme (bir standart oluşturmak için belirlenen görevle ilgili öğrenci çalışmalarının toplanması ve uzmanlarla paylaşı|ması),

6. Uzman görüşlerinin değerlendirilmesi ve ölçeğin gözden geçirilmesi.

1. Ölçeğin geliştirilme amacı: Ortaokul öğrencilerinin, okuduklarını anlayarak eleştirel bir bakış açısıyla sorgulama ve değerlendirme yapmalarına yönelik (MEB, 2018, s. 8) bir değerlendirme aracı oluşturmaktır.

2. Değerlendirme kriterlerinin belirlenmesi: Bu aşamada literatür taraması yapılmış ve Türkçe derslerinde öyküleyici metinler aracılı̆̆ıyla eleştirel düşünme becerilerini değerlendirmeye yönelik önemli görülen gözlemlenebilir kriterler belirlenmiştir. Okuduğunu anlayarak eleştirel bir bakış açısıyla düşünmeyi değerlendirmenin en etkili yollarından biri okuma metniyle ilgili açık uçlu soruların sorulmasıdır. Bunun için bir okuma metninde, belirlenen kriterlerin gözlemlenmesini sağlayacak soruların neler olabileceği, eleştirel düşünmeyle ilgili daha önce hazırlanan kaynaklar incelenerek (King, 1985; MacKnight, 2000; Learning Development, 2010; Facione, 2015) Türkçe derslerinde eleştirel düşünme beceri kriterlerine uygun soru tipleri/kökleri belirlenmeye çalışılmıştır (EK-1). Uzman görüşü alındıktan sonra (bkz. Tablo. 5) metnin içeriğini anlama için tanımlama ve yorumlama; metne derinlemesine bakış için ise analiz, çıkarım, açıklama, varsayımda bulunma ve değerlendirme kriterleri eleştirel düşünme becerileri olarak belirlenmiştir.

3. Kriterler için yeterlik düzeylerinin değerlendirilmesi: Herhangi bir öyküleyici metinde, öğrencilerin her bir kriteri karşılamak üzere, kriterler kısmında belirlenen sorulara verebileceği cevaplar üzerinde beyin fırtınası yapılarak performans düzeyleri tespit edilmiştir. Performans düzeyleri yaygın olarak 3'lü, 4'lü veya 5'li hazırlanmaktadır (Roberts, 2008, s. 23). Bu çalışmada performans düzeyleri hem nicel (0-4) hem de nitel terimlerle (ör. geliştirilebilir) ifade edilerek beş düzeye ayrılmıştır. (Rubrik, deneme aşamasında 4 düzeyli olarak da denenmiş ancak performans düzeyleri arasındaki ara seviyelerin 5 düzeyli olarak daha iyi ifade edildiği sonucuna varılmıştır.) Performans düzeyini karşılayan ifadeler şöyledir: 
0 , öğrencinin soruya cevap veremediğini, "yetersiz" olduğunu gösterir.

1 , öğrencinin verdiği cevabın " $a z$ yeterli" olduğunu gösterir.

2, öğrencinin verdiği cevabın "geliştirilebilir" olduğunu gösterir.

3, öğrencinin verdiği cevabın "yeterli" olduğunu gösterir.

4, öğrencinin verdiği cevabın "oldukça yeterli" olduğunu gösterir.

4. Her bir kriter için düzeylerin tanımlanması: Performans düzeyleri belirlendikten sonra kriterler, performans düzeyiyle tutarlı şekilde ayrı ayrı tanımlanmıştır. Tanımlama yapııırken öncelikle her bir kriter için beklenen en yüksek (4) ve en düşük (0) performans düzeyi tanımlanmış böylelikle beklenen performansla ilgili en üst ve en alt sınırlar belirlenerek diğer düzeylerin tanımlanması için taban ölçütler oluşturulmuştur. Daha sonra orta ve ara düzeyler için açıklayıcı tanımlamalar yapılmıştır. Tanımlamalar arasındaki tutarlıı̆ı sağlamak için performans düzeyleri arasındaki farkı açıkça gösteren ifadeler belirlenmiş ve vurgulanmıştır. Bunlar genel olarak şöyle özetlenebilir:

- 0 "yetersiz": Öğrencinin belirlenen kriterle ilgili kendisinden beklenen performansı sergileyemediğini (sorulara cevap veremediğini) gösterir.

- 1, "az yeterli": Öğrencinin belirlenen kriterle ilgili performans sergilediğini, ancak bu performansın minimum düzeyde olduğunu (ör. en çok 1 örneğin verilmesi ya da 1 doğrunun bulunması) veya cevabın yanlış/metinle ilgisiz olduğunu gösterir.

- 2, "geliştirilebilir": Öğrencinin belirlenen kriterle ilgili "orta düzeyde kabul edilebilir bir performans sergilediğini, ancak gerekçe gösterme, ipuçlarından yararlanma gibi ayırıcı özellikleri yerine getiremediğini gösterir.

- 3, "yeterli": Öğrencinin belirlenen kriterle ilgili yeterli düzeyde bir performans sergilediğini ve soruların çoğuna cevap verme, en az bir tane gerekçe sunma, ipuçlarından yararlanma gibi ayırıcı özellikleri yerine getirdiğini gösterir.

- 4, "oldukça yeterli": Öğrencinin belirlenen kriterlerle ilgili en üst düzeyde performans sergilediğini ve soruların hepsine cevap verme, birden fazla gerekçe sunma, ipuçları kullanma gibi ayırıcı özellikleri tam olarak yerine getirdiğini gösterir.

5. Rubriği deneme: Deneme aşamasında belirlenen kriterlere uygun 1 metin belirlenmiştir. Seçilen metinle ilgili belirlenen kriterlerin değerlendirilmesi için önceden hazırlanan soru tiplerinden (EK-1) yararlanılarak 22 tane açık uçlu okuma sonrası sorusu oluşturulmuştur. Hazırlanan sorular 9 uzman tarafından değerlendirilmiştir. Uzmanlardan gelen görüşler doğrultusunda içeriği anlamayla ilgili 7, derinlemesine bakışla ilgili 5 soru kullanılmak üzere seçilmiştir. Kriter tanımlamalarında ve sorularda yapılan düzenlemelerden sonra rubriğe ilk hâli verilmiştir.

Bu düzenlemelerden sonra, rubrik denenmek üzere uygulanmıştır. Her seviyeyi örneklendiren öğrenci çalışmalarını toplamak için farklı il ve bölgelerdeki 6. sınıf öğrencileri üzerinde uygulama 
yapılmıştır. Tamamı resmî okullar olmak üzere, İstanbul/Sarıyer'deki bir ortaokulda 6, Bursa/Yıldırım'daki bir ortaokulda 6, Giresun il merkezine bağlı bir köy ortaokulunda 5, Antalya/Kemer'deki bir ortaokulda 7 olmak üzere toplam 4 ortaokulda 24 öğrenciye rubrik uygulanmıştır. Uygulamayı yapan öğretmenlere rubrik tanıtılarak nasıl değerlendirme yapacakları anlatılmıştır. Ayrıca öğretmenlere olası cevapları değerlendirmelerine yardımcı olacak bir cevap anahtarı da verilmiştir.

Dört öğretmenden gelen geri bildirime göre rubriğin yorumlama kriterinde bulunan, "metinde yer alan olaylar arasında ilişki kurma ve ana fikir bulma" kısmında düzenleme yapılmıştır. "Açıklama", "varsayımda bulunma" ve "değerlendirme" düzeylerindeki kriter tanımlamalarında da düzenleme yapılmıştır. Örneğin varsayımda bulunma kriterinin (4) Oldukça yeterli performans düzeyinde bulunan "Verilen durumla ilgili en az iki mantıklı varsayımda bulunur." tanımlaması, "Verilen durumla ilgili yaratıcı, alternatif ve mantıklı varsayım(lar)da bulunur." şeklinde değiştirilmiştir.

Yapılan değişiklikten sonra rubrik farklı düzeylerdeki 6 tane 6. sınıf öğrencisi (Antalya/Kemer), 6 tane de 7. sınıf öğrencisi (İstanbul/Sarıyer) olmak üzere toplam 12 öğrenciye tekrar uygulanmış ve geri bildirimler alınmıştır. Değerlendirmeyi yapan 2 öğretmen ölçeğin düzenlenmiş hâlinin daha kullanışlı olduğunu ve "olaylar arası ilişki kurma", "çıkarım", "açıklama", "varsayımda bulunma", "değerlendirme" kriterlerinin daha detaylı tanımlanabileceği önerisini getirmiş̧ir. Bu düşünce alan uzmanlarıyla istişare edilmiş ve tanımlar "analiz" kısmıyla sınırlı olacak şekilde yeniden düzenlemiştir. Örneğin varsayımda bulunma kriterinin (4) Oldukça yeterli performans düzeyinde yapılan "Verilen durumla ilgili yaratıcı, alternatif ve mantıklı varsayım(lar)da bulunur." ifadesi, "Verilen durumla ilgili yaratıcı, alternatif ve mantıklı varsayım(lar)ını gerekçeleriyle sunar." şeklinde değiştirilmiştir. Bu değişiklikten sonra rubrik aynı öğretmenler tarafından öncekilerden farklı 4 öğrenciye tekrar uygulanmış ve uygulamayı yapan 2 öğretmenden geri bildirim alınmıştır. Öğretmenler, değerlendirme yaparken bir sorunla karşılaşmadıklarını ve rubriğin son hâlinin değerlendirme için uygun olduğunu ifade etmişlerdir.

6. Uzman görüşlerinin değerlendirilmesi ve rubriğin denenmesi: Rubrikle ilgili deneme çalışmaları yapıldıktan sonra kriterleri tanımlayan özellikler alan uzmanları tarafından son kez gözden geçirilmiştir. Alan uzmanları tarafından yapılan son değerlendirmede "analiz ve çıkarım" kriterlerini açıklayan bazı performans düzeylerindeki ifadelerde düzenleme yapılmış ve ölçeğe son hâli verilerek geçerli bir rubrik oluşturulmuştur. (Örneğin çıkarım kriterinde "Metinle ilgili en az 2 çıkarım yapar ve gerekçesini sunar." ifadesi, "Metinle ilgili çıkarımları gerekçesiyle sunar." şeklinde değiştirilmiştir.) 


\section{Geçerlik ve Güvenirlik Çalışmaları}

İyi bir ölçme yapabilmek için ölçme aracında bulunması gereken temel özelliklerden en önemli ikisi geçerlik ve güvenirliktir (Karasar, 2012, s. 147). Geçerlik, değerlendirme amacına bağlı olarak ölçme aracının ölçmeyi amaçladığı şeyi doğru olarak ölçmesidir (Yıldırım ve Şimşek, 2013, s. 289). Ölçek geliştirme çalışmaları deneysel ya da kuramsal süreçlerle gerçekleşir. Kuramsal çalışmalarda ölçmeye konu olan özellik kapsamında uzman görüşlerine başvurulur. Nitel çalışmayla elde edilen uzman görüşleri kapsam geçerlik oranlarıyla nicel sürece dönüşmektedir (McGartland vd., 2003). Bu kapsamda dereceli puanlama anahtarlarının geçerliğine "içerik, yapı ve/veya ölçüt/kriter" yönüyle bakılabilir (Moskal ve Leydens, 2000, 1-3).

Kapsam geçerlik oranları yani ölçütleri Lawshe (1975) tarafından geliştirilmiştir. Lawshe tekniği olarak bilinen bu yaklaşım 6 adımda gerçekleşmektedir:

- Alan uzmanları grubunun oluşturulması,

- Aday ölçek formlarının oluşturulması,

- Uzman görüşlerinin elde edilmesi,

- Maddelere ilişkin kapsam geçerlik oranlarının elde edilmesi,

- Ölçeğe ilişkin kapsam geçerlik indekslerinin elde edilmesi,

- Kapsam geçerlik oranları/indeksi ölçütlerine göre nihai formun oluşturulması.

Lawshe tekniğine göre en az 5 en fazla 40 uzmanın görüşüne ihtiyaç duyulur. Kapsam geçerlik oranları elde edilirken uzmanların herhangi bir maddeye ilişkin görüşleri toplanır. Kapsam geçerlik oranları (KGO); herhangi bir maddeye ilişkin "gerekli" görüşünü belirten uzman sayısının, maddeye ilişkin görüş belirten toplam uzman sayısına oranının 1 eksiği hesaplanarak bulunur.

$$
\mathrm{KGO}=\frac{N G}{N / 2}-1
$$

Burada NG maddeye gerekli diyen uzman sayısını, $\mathrm{N}$ ise görüş bildiren toplam uzman sayısını göstermektedir. KGO negatif ya da 0 olan maddeler ilk etapta elenmektedir. KGO değerleri pozitif olan maddeler için istatistiksel ölçütler ile anlamlılıkları test edilir. Nihai forma alınacak maddelerin $(\alpha=.05$ anlamlılık düzeyinde) toplam KGO ortalamaları üzerinden kapsam geçerlik indeksleri (KGi) elde edilir. KGO değerlerinin minimum değerleri (kapsam geçerlik ölçütleri) Veneziano ve Hooper (1997) tarafından tabloya dönüştürülmüştür. Buna göre uzman sayısına ilişkin minimum değerler aynı zamanda maddenin istatistiksel anlamlılı̆ını da vermektedir (akt. Yurdagül, 2005, s. 2). 
Tablo 4. $\alpha=.05$ anlamlılık düzeyinde KGO için minimum değerler

\begin{tabular}{ll|ll}
\hline Uzman sayısı & Min. Değer & Uzman sayısı & Min. Değer \\
\hline 5 & 0.99 & 13 & 0.54 \\
6 & 0.99 & 14 & 0.51 \\
7 & 0.99 & 15 & 0.49 \\
8 & 0.78 & 20 & 0.42 \\
9 & 0.75 & 25 & 0.37 \\
10 & 0.62 & 30 & 0.33 \\
11 & 0.59 & 35 & 0.31 \\
12 & 0.56 & 40 & 0.29
\end{tabular}

akademisyenin ve 4 Türkçe öğretmenin (mesleki deneyimi 8 yıl ve üstü) görüşlerine başvurulmuştur. Uzmanlardan, rubrik maddelerinin ölçülmek istenen özelliği temsil edip etmediğiyle ilgili görüş bildirmeleri istenmiştir. Uzmanlar belirtilen kriterler için "Madde gerekli", "Madde yararlı ancak yetersiz", "Madde gereksiz" şeklinde görüş belirtmiştir. Ayrıca çalışmaya katkı sağlayacak öneri ve görüşlerinin olup olmadığı da sorulmuştur. Literatür taraması sonucunda aday ölçek formunda bulunan 14 maddeden 7 tanesi nihai formda yer almıştır. Yani 9 uzman için kapsam geçerlik oranı KGO=0.75'in altında kalan maddeler forma dâhil edilmemiştir. Minimum değerleri anlamlı çıkan her bir maddenin KGO ortalaması kapsam geçerlik indeksini (KGi) verir. Ölçek, birden fazla bölümden oluştuğu için her bölümün kapsam geçerlik indeksi ayrı (KGi) değerlendirilmiştir. KGO tablo 5'te gösterilmiştir.

Tablo 5. Maddelerin Kapsam Geçerlik Oranları ve Indeksleri

\begin{tabular}{|c|c|c|c|c|c|c|}
\hline & & Gerekli & $\begin{array}{l}\text { Yararlı } \\
\text { /Yetersiz }\end{array}$ & Gereksiz & KGO & KGi \\
\hline İçeriği Anlama & $\begin{array}{l}\text { Tanımlama } \\
\text { Yorumlama } \\
\text { Uygulama }\end{array}$ & $\begin{array}{l}9 \\
8 \\
0\end{array}$ & $\begin{array}{l}0 \\
1 \\
1\end{array}$ & $\begin{array}{l}0 \\
0 \\
8\end{array}$ & $\begin{array}{l}1 \\
0,78 \\
-1\end{array}$ & 0,89 \\
\hline $\begin{array}{l}\text { Derinlemesine } \\
\text { Anlama/Bakış }\end{array}$ & $\begin{array}{l}\text { Tümdengelim } \\
\text { Tümevarım } \\
\text { Analiz } \\
\text { Çıkarım } \\
\text { Karşı Görüşlerin } \\
\text { Değerlendirilmesi }\end{array}$ & $\begin{array}{l}3 \\
4 \\
9 \\
8\end{array}$ & $\begin{array}{l}0 \\
0 \\
0 \\
1\end{array}$ & $\begin{array}{l}6 \\
5 \\
0 \\
0\end{array}$ & $\begin{array}{l}-0,33 \\
-0,11 \\
1 \\
0,78 \\
-1\end{array}$ & 0,87 \\
\hline
\end{tabular}




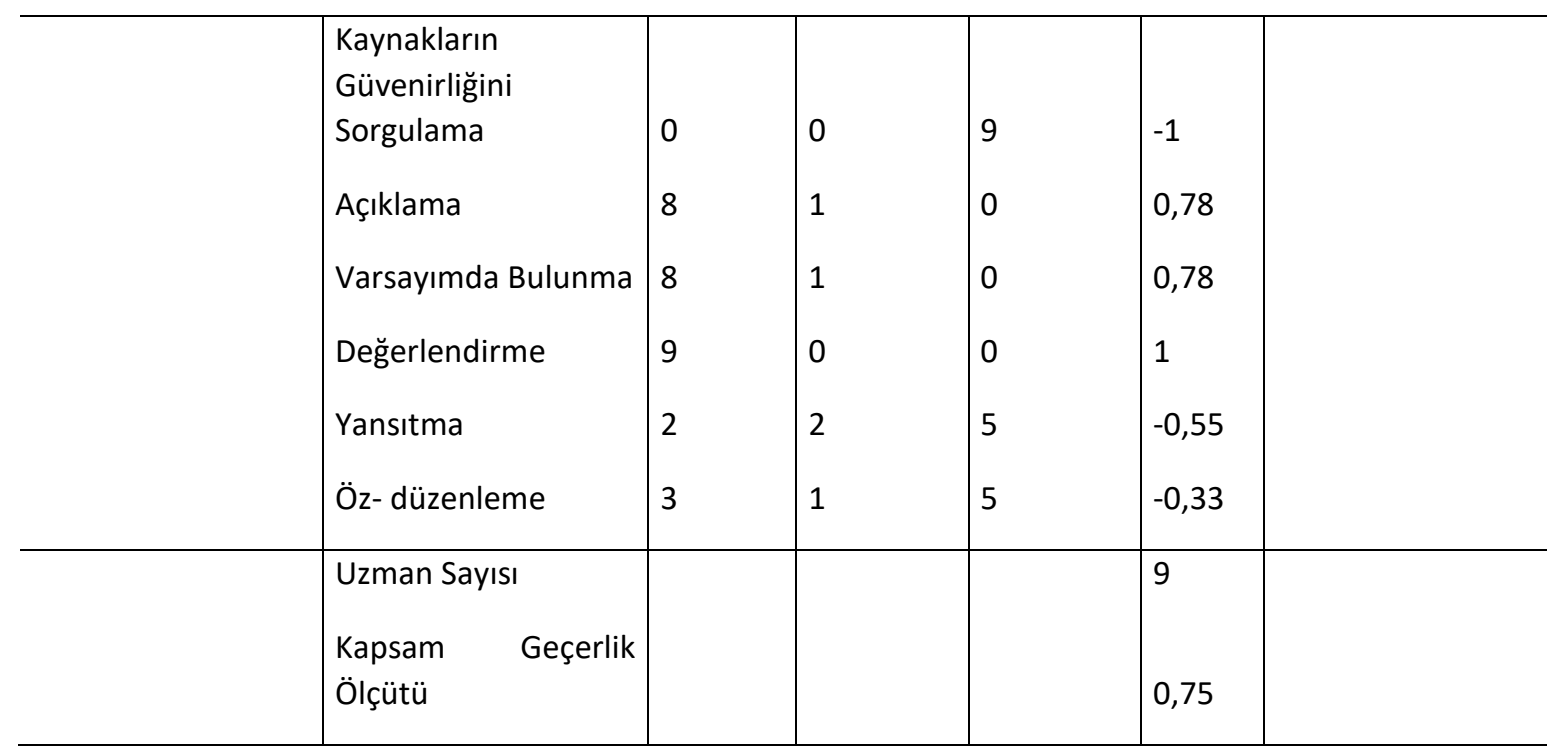

Tablo 4 ve Tablo 5 birlikte değerlendirildiğinde uzman görüşleri doğrultusunda 9 uzman için minimum kapsam geçerlik oranı değeri 0.75 'in altında kalan maddeler forma alınmamıştır. İçeriği anlama için $\mathrm{KGI}=0,89$; Derinlemesine bakış için $\mathrm{KGI}=0,87$ bulunmuştur. Ölçek boyutlarının kapsam geçerlik indeksleri 9 uzman için 0.75 'in üzerinde olduğundan hazırlanan formun geçerli bir form olduğu söylenebilir. Uzmanlar tümdengelim, tümevarım, karşı görüşlerin değerlendirilmesi, kaynakların güvenirliğini sorgulama, yansıtma ve öz-düzenleme kriterlerinin analiz, değerlendirme, çıkarım, açıklama gibi madde tanımlarıyla benzerlik gösterdiğini bu bakımdan ayrı bölümler hâlinde verilmesine gerek olmadığını belirtmişlerdir. Yapılan analiz sonucunda içeriği anlama için tanımlama, yorumlama; derinlemesine bakış için analiz, çıkarım, açıklama, varsayımda bulunma ve değerlendirme maddeleri öyküleyici metinler için eleştirel düşünme becerileri olarak belirlenmiştir.

Güvenirlik, aynı şeyin bağımsız ölçümleri arasındaki kararlılık (istikrar); aynı ölçütler kullanılarak aynı süreçlerden aynı sonuçların alınması olarak tanımlanmaktadır. Genellikle üç tür güvenirlik söz konusudur: zamana göre değişmezlik (süreklilik), bağımsız gözlemciler arası uyum, iç tutarlılık (Karasar, 2012, s. 148).

Moskal ve Leydens $(2000$, s. 4) "test-tekrar test güvenirliği, eş değer formlar güvenirliği, yarıya bölme güvenirliği, rasyonel denklik güvenirliği" gibi terimlerin belirli bir testte ya da birden çok testte öğrenci performanslarının tutarlılığını sağlamak için kullanılan istatistiksel yöntemler olduğunu ifade etmektedir. Bu güvenirlik türleri, sınıf içi değerlendirmeden çok standartlaştırılmış testlerde kullanılmaktadır.

Sınıf içi değerlendirmelerde ve rubrik geliştirme çalışmalarında genellikle puanlayıcı / değerlendirici güvenirliğine dayalı iki güvenirlik biçimi dikkate alınmaktadır. Puanlayıcı güvenirliği, genellikle iki bağımsız değerlendirmeci tarafından verilen puanlar ya da aynı değerlendirmeci tarafından farklı zamanlarda verilen puanlar arasındaki tutarlılı̆ı ifade etmektedir. Bunlardan 
birincisine "değerlendirmeciler arası güvenirlik", ikincisine ise "değerlendiricinin kendi içindeki güvenirliği" adı verilmektedir (Moskal ve Leydens, 2000, s. 4).

Bu çalışmanın güvenirliği “bağımsız değerlendirmeciler arası uyum güvenirliği” ile sağlanmıştır. Analitik rubrik geliştirme çalışmalarında değerlendirmeciler arası uyum çalışmalarından yararlanılmaktadır (Örneğin, Beyreli ve Arı, 2009; Öztürk ve Güdek, 2016). Bağımsız değerlendirmeciler arası uyumu hesaplamak için korelasyon ve varyans çözümlemelerinden yararlanılır. Varyans çözümlemeleri, ikiden çok değerlendirmecinin bulunduğu durumlarda kullanılır (Karasar, 2012, s. 149).

Uzman görüşleriyle son şekli verilmiş olan rubrikle bir pilot uygulama yapılmıştır. Pilot uygulama İstanbul ve Antalya'da iki farklı ortaokulda bulunan 6. ve 7. sınıf öğrencileriyle gerçekleşmiştir. Uygulamaya 110 öğrenci katılmıştır. Bu 110 öğrencinin verdiği cevaplardan (28 tanesi 6. sınıf, 27 tanesi 7. sınıf olmak üzere) 55 tanesi hazırlanan rubriğe göre araştırmacı ve iki farklı Türkçe öğretmeni tarafından değerlendirilmiş ve dağılım normal olduğu için puanlar arasındaki pearson korelasyona bakılmıştır. Değerlendirmeye başlamadan önce öğretmenlerle görüşülmüş ve ölçeğin nasıl kullanılacağı açıklanmıştır. Değerlendirmeyi kendilerine verilen cevap anahtarındaki açıklamalara göre yapmaları istenmiştir. Yapılan analiz sonucunda değerlendirmeciler arasında pozitif ve anlamlı bir ilişkinin olduğu görülmüştür.

Tablo 6. Rubriğin maddelerine göre değerlendirmeciler arası uyuma ilişkin korelasyon analizi sonuçları

\begin{tabular}{|c|c|c|c|c|c|c|c|c|c|}
\hline & $\mathrm{d} 1-\mathrm{d} 28$ & & & d1-d2 & & & d1-d3 & & \\
\hline & $r$ & $\mathrm{sd}$ & $\mathrm{p}$ & $r$ & sd & $\mathrm{p}$ & $r$ & sd & $\mathrm{p}$ \\
\hline s.1a-tanımlama & 0,930 & 55 & $p<.01$ & 1,000 & 26 & $p<.01$ & 0,858 & 27 & $p<.01$ \\
\hline s.1b-tanımlama & 0,917 & 55 & $p<.01$ & 1,000 & 26 & $p<.01$ & 0,556 & 27 & $p<.01$ \\
\hline s.1c-tanımlama & 1,000 & 55 & $\mathrm{p}<.01$ & 1,000 & 26 & $p<.01$ & 1,000 & 27 & $p<.01$ \\
\hline s.1d-tanımlama & 0,931 & 55 & $p<.01$ & 0,919 & 26 & $p<.01$ & 0,894 & 27 & $\mathrm{p}<.01$ \\
\hline s.2a-yorumlama & 0,876 & 55 & $\mathrm{p}<.01$ & 0,934 & 26 & $p<.01$ & 0,701 & 27 & $\mathrm{p}<.01$ \\
\hline s.2b-yorumlama & 0,883 & 55 & $p<.01$ & 0,937 & 26 & $p<.01$ & 0,821 & 27 & $\mathrm{p}<.01$ \\
\hline s.2c-yorumlama & 0,964 & 55 & $p<.01$ & 0,964 & 26 & $p<.01$ & 0,961 & 27 & $\mathrm{p}<.01$ \\
\hline s.3-analiz & 0,877 & 55 & $p<.01$ & 0,899 & 26 & $p<.01$ & 0,851 & 27 & $\mathrm{p}<.01$ \\
\hline s.4-çıkarım & 0,880 & 55 & $p<.01$ & 0,894 & 26 & $p<.01$ & 0,867 & 27 & $\mathrm{p}<.01$ \\
\hline s.5-açıklama & 0,922 & 55 & $p<.01$ & 0,949 & 26 & $p<.01$ & 0,845 & 27 & $\mathrm{p}<.01$ \\
\hline s.6-varsayımda bulunma & 0,929 & 55 & $\mathrm{p}<.01$ & 0,933 & 26 & $p<.01$ & 0,899 & 27 & $p<.01$ \\
\hline s.7-değerlendirme & 0,853 & 55 & $\mathrm{p}<.01$ & 0,857 & 26 & $\mathrm{p}<.01$ & 0,849 & 27 & $\mathrm{p}<.01$ \\
\hline
\end{tabular}

Tablo 6'ya bakıldığında tanımlama maddesinde bulunan 1a $(0,930), 1 b(0,917), 1 c(1,000)$ ve 1d $(0,931)$ sorularına ilişkin; 1 , 2. ve 3 . değerlendirmecinin puan ortalamaları arasında çok yüksek, 
pozitif yönlü ve anlamlı bir ilişkinin $(p<.01)$ olduğu görülmektedir. Yorumlama maddesini karşılayan 2a $(0,876)$ ve $2 b(0,883)$ sorularında yüksek, pozitif yönlü ilişkinin; $2 c(0,964)$ sorusunda ise çok yüksek, pozitif yönlü anlamlı bir ilişkinin olduğu görülmektedir. Analiz maddesini karşılayan 3. $(0,877)$ soruda, çıkarım maddesini karşılayan 4. $(0,880)$ ve değerlendirme maddesini karşılayan $7 .(0,853)$ soruda yüksek, pozitif yönlü ilişkinin; açıklama maddesini karşılayan 5. $(0,922)$ soruya ve varsayımda bulunma maddesini karşılayan 6. $(0,929)$ soruya verilen cevapların değerlendirilmesinde çok yüksek, pozitif yönlü ve anlamlı bir ilişkinin olduğu görülmektedir. Tabloya göre, rubriği kullanarak farklı zamanda ve mekânda puanlama yapan değerlendirmecilerin değerlendirme sonuçları birbiriyle ilişkilidir. Farklı değerlendirmeciler, aynı ölçütlerle benzer sonuçlara ulaşmıştır.

Türkçe derslerinde, metni anlayarak metinle ilgili eleştirel düşünme becerilerinin değerlendirilmesi için hazırlanan rubriğin güvenirliğini artırmak için ortaokul derecesinde her sınıf düzeyinden öğrencinin yer aldığı büyük bir grupla çalışılmıştır. Bu amaçla hazırlanan rubrik; İstanbulAtaşehir, İstanbul-Pendik, Kocaeli-Gebze, Bursa-Yıldırım ve Antalya-Kemer ilçelerindeki ortaokullara devam eden 5, 6, 7 ve 8. sınıflardan 652 öğrenciye uygulanmıştır. Elde edilen verilerden rastgele (5. sınıflardan 50, 6. sınıflardan 52, 7. sınıflardan 50 ve 8. sınıflardan 50) olmak üzere 202 kâğıt değerlendirilmek için seçilmiştir. Seçilen kâğıtlar, cevap anahtarıyla birlikte değerlendirilmek üzere 4 Türkçe öğretmenine ulaştırılmıştır. Değerlendirmeciler ölçeğin nasıl kullanılacağına dair bilgilendirilmiş ve değerlendirmeyi, kendilerine verilen sıraya göre yapmaları gerektiği belirtilmiştir. Değerlendirme işlemleri 2 aylık bir sürede tamamlanmıştır.

\section{Verilerin Analizi}

Verilerin analizinde SPSS 22 yazılımından yararlanılmıştır. Geçerlik için Lawshe analizi; puanlayıcı güvenirliğini sağlamak için pearson korelasyon analizi yapılarak ortalamalar arası puan farkında fark olmadığını göstermek için varyans analizi yapılmıştır.

\section{Bulgular}

Bu kısımda rubriğin geliştirilmesi amacıyla yapılan güvenirlik analizlerinin sonuçları ortaya konmuştur.

Tablo 7. 1. Boyut maddelerine göre değerlendirmeciler arası uyuma ilişkin korelasyon analizi sonuçları

\begin{tabular}{llllll}
\hline içeriği anlama & & Gözlemci 1 & Gözlemci 2 & Gözlemci 3 & Gözlemci 4 \\
\hline Gözlemci 1 & Pearson Korelasyon & 1 &, $981^{* *}$ &, $991^{* *}$ &, $995^{* *}$ \\
& Sig. (2-tailed) & &, 000 &, 000 &, 000 \\
& $\mathrm{~N}$ & 202 & 202 & 202 & 202 \\
Gözlemci 2 & Pearson Korelasyon &, $981^{* *}$ & 1 &, $975^{* *}$ &, $977^{* *}$ \\
& Sig. (2-tailed) &, 000 & &, 000 &, 000 \\
& $\mathrm{~N}$ & 202 & 202 & 202 & 202
\end{tabular}




$\begin{array}{llllll}\text { Gözlemci } 3 & \text { Pearson Korelasyon } & , 991^{* *} & , 975^{* *} & 1 & , 987^{* *} \\ & \text { Sig. (2-tailed) } & , 000 & , 000 & & 202 \\ \text { Gözlemci } 4 & \text { N } & 202 & 202 & 202 & 1 \\ & \text { Searson Korelasyon } & , 995^{* *} & , 977^{* *} & , 987^{* *} & 1 \\ & \text { Sig.tailed) } & , 000 & , 000 & 2002 & 202\end{array}$

**. Correlation is significant at the 0.01 level (2-tailed).

Tablo 7'ye bakıldığında, değerlendirmecilerin 1 . boyutta yer alan maddelere (tanımlama ve yorumlama) ilişkin puan ortalamaları korelasyonu arasında 1-2 (0, 981), 1-3 (0,991), 1-4 (0,995); 2-3 $(0,975), 2-4(0,977)$; 3-4 (0,987) çok yüksek, pozitif yönlü ve anlamlı bir ilişkinin olduğu görülmektedir $(p<.01)$. Yani 4 farklı değerlendirmeci tanımlama, yorumlama maddelerinde bulunan 7 soruyu benzer şekilde değerlendirmiştir.

Tablo 8. 2. boyut maddelerine göre değerlendirmeciler arası uyuma ilişkin korelasyon analizi sonuçları

\begin{tabular}{|c|c|c|c|c|c|}
\hline \multicolumn{2}{|c|}{ derinlemesine anlama } & \multirow{2}{*}{$\begin{array}{l}\text { Gözlemci } 1 \\
1\end{array}$} & \multirow{2}{*}{$\begin{array}{l}\text { Gözlemci } 2 \\
, 961^{* *}\end{array}$} & \multirow{2}{*}{$\begin{array}{l}\text { Gözlemci } 3 \\
, 980^{* *}\end{array}$} & \multirow{2}{*}{$\begin{array}{l}\text { Gözlemci } 4 \\
993^{* *}\end{array}$} \\
\hline Gözlemci 1 & Pearson Korelasyon & & & & \\
\hline & Sig. (2-tailed) & & ,000 & ,000 & ,000 \\
\hline & $\mathrm{N}$ & 202 & 202 & 202 & 202 \\
\hline \multirow[t]{3}{*}{ Gözlemci 2} & Pearson Korelasyon &, $961^{* *}$ & 1 &, $943^{* *}$ &, $955^{* *}$ \\
\hline & Sig. (2-tailed) & ,000 & & ,000 & ,000 \\
\hline & $\mathrm{N}$ & 202 & 202 & 202 & 202 \\
\hline \multirow[t]{3}{*}{ Gözlemci 3} & Pearson Korelasyon & $980^{* *}$ &, $943^{* *}$ & 1 & $976^{* *}$ \\
\hline & Sig. (2-tailed) & ,000 & ,000 & & ,000 \\
\hline & $\mathrm{N}$ & 202 & 202 & 202 & 202 \\
\hline \multirow[t]{3}{*}{ Gözlemci 4} & Pearson Korelasyon &, $993^{* *}$ &, $955^{* *}$ & $976^{* *}$ & 1 \\
\hline & Sig. (2-tailed) & ,000 & ,000 & ,000 & \\
\hline & $\mathrm{N}$ & 202 & 202 & 202 & 202 \\
\hline
\end{tabular}

**. Correlation is significant at the 0.01 level (2-tailed).

Tablo 8'e bakıldığında, değerlendirmecilerin, rubriğin 2. boyutunda yer alan maddelerine (analiz, çıkarım, açıklama, varsayımda bulunma, değerlendirme) ilişkin puan ortalamaları korelasyonu arasında 1-2 (0, 961), 1-3 (0,980), 1-4 (0,993); 2-3 (0,943), 2-4 (0,955); 3-4 (0,976) çok yüksek, pozitif yönlü ve anlamlı bir ilişkinin olduğu görülmektedir (p<.01). Yani 4 farklı değerlendirmeci analiz, çıkarım, açıklama, varsayımda bulunma ve değerlendirme maddelerinde sorulan sorulara verilen cevapları benzer şekilde değerlendirmiştir. 
Değerlendirmecilerin, rubrikte yer alan her bir maddeye ilişkin puanlamaları arasındaki farkın anlamlı olup olmadığını anlamak amacıyla yani ortalamalar arasındaki farkı belirlemek amacıyla ANOVA analizi yapılmıştır.

Tablo 9. Değerlendirmecilerin Eleştirel Düşünme Maddelerine Göre Ortalama Puan Farklarının Farkına Illişkin Varyans Analizi Sonuçları

\begin{tabular}{|c|c|c|c|c|c|c|}
\hline & & Kareler Toplamı & sd & Kareler Ortalaması & $\mathrm{F}$ & $\mathrm{p}$ \\
\hline \multirow[t]{3}{*}{ s.1a } & Gruplar arası & ,014 & 3 & ,005 & ,020 & ,996 \\
\hline & Grup içi & 179,431 & 804 & ,223 & & \\
\hline & Toplam & 179,444 & 807 & & & \\
\hline \multirow[t]{3}{*}{ s.1b } & Gruplar arası & 0,000 & 3 & 0,000 & 0,000 & 1,000 \\
\hline & Grup içi & 118,337 & 804 & 147 & & \\
\hline & Toplam & 118,337 & 807 & & & \\
\hline \multirow[t]{3}{*}{ s.1c } & Gruplar arası & 0,000 & 3 & 0,000 & 0,000 & 1,000 \\
\hline & Grup içi & 58,931 & 804 & ,073 & & \\
\hline & Toplam & 58,931 & 807 & & & \\
\hline \multirow[t]{3}{*}{ s.1d } & Gruplar arası & 024 & 3 & ,008 & ,031 & ,993 \\
\hline & Grup içi & 201,698 & 804 & ,251 & & \\
\hline & Toplam & 201,722 & 807 & & & \\
\hline \multirow[t]{3}{*}{ s. $2 \mathrm{a}$} & Gruplar arası & 261 & 3 & 087 & 132 & 941 \\
\hline & Grup içi & 530,856 & 804 & ,660 & & \\
\hline & Toplam & 531,118 & 807 & & & \\
\hline \multirow[t]{3}{*}{ s. $2 b$} & Gruplar arası & ,223 & 3 & ,074 & ,049 & ,986 \\
\hline & Grup içi & 1221,693 & 804 & 1,520 & & \\
\hline & Toplam & 1221,916 & 807 & & & \\
\hline \multirow[t]{3}{*}{ s. $2 \mathrm{c}$} & Gruplar arası & ,043 & 3 & ,014 & ,009 & 999 \\
\hline & Grup içi & 1318,609 & 804 & 1,640 & & \\
\hline & Toplam & 1318,652 & 807 & & & \\
\hline \multirow[t]{3}{*}{ s.3 } & Gruplar arası & ,360 & 3 & 120 & 206 & ,892 \\
\hline & Grup içi & 468,520 & 804 & ,583 & & \\
\hline & Toplam & 468,880 & 807 & & & \\
\hline \multirow[t]{3}{*}{ s.4 } & Gruplar arası & ,024 & 3 & ,008 & ,013 & ,998 \\
\hline & Grup içi & 502,946 & 804 & ,626 & & \\
\hline & Toplam & 502,969 & 807 & & & \\
\hline
\end{tabular}




\begin{tabular}{|c|c|c|c|c|c|c|}
\hline \multirow[t]{3}{*}{ s.5 } & Gruplar arası & 172 & 3 & ,057 & 128 & ,944 \\
\hline & Grup içi & 360,936 & 804 & ,449 & & \\
\hline & Toplam & 361,108 & 807 & & & \\
\hline \multirow[t]{3}{*}{ s. 6} & Gruplar arası & ,054 & 3 & ,018 & ,021 & 996 \\
\hline & Grup içi & 705,010 & 804 & ,877 & & \\
\hline & Toplam & 705,064 & 807 & & & \\
\hline \multirow[t]{3}{*}{ s.7 } & Gruplar arası & 782 & 3 & 261 & ,356 & 784 \\
\hline & Grup içi & 588,069 & 804 & ,731 & & \\
\hline & Toplam & 588,851 & 807 & & & \\
\hline
\end{tabular}

Tablo 9 incelendiğinde değerlendirmecilerin eleştirel düşünme rubriğinde yer alan her bir maddeye ilişkin puanlamaları arasında fark olmadığı görülmektedir (p>.05). Yani değerlendirmecilerin rubriği kullanarak her bir soruya verilen cevaplar için puanlama ortalamaları birbirine benzerdir, ortalamalar arasında anlamlı bir fark yoktur. Elde edilen bu sonuçlar hazırlanan rubriğin güvenirliğini ortaya koymaktadır.

\section{Sonuç ve Tartışma}

Bu çalışmada, öğrencilerin Türkçe derslerinde okudukları bir metnin içeriğini anlamaları ve o konu üzerine derinlemesine düşünmelerini sağlamak amacıyla belirli performans kriterlerinde açık uçlu sorular hazırlanarak öğrencilerin eleştirel düşünme becerilerinin geliştirilmesine yönelik uygulamalar yapılmıştır. Yapılan bu uygulamaları değerlendirmek amacıyla öyküleyici metinlerde kullanılmak üzere "içeriği anlama" ve "derinlemesine anlama/bakış" olmak üzere iki boyuttan oluşan analitik (çözümleyici) bir eleştirel düşünme rubriği hazırlanmıştır. Türkçe derslerinde öyküleyici metinler aracılığıyla eleştirel düşünme becerilerinin değerlendirilmesinde kullanılacak soru tiplerinin belirlenmesi, performansa dayalı değerlendirme kriterlerinin, yeterlik düzeylerinin nasıl olması gerektiği ve kriter düzeylerinin nasıl tanımlanabileceğine yönelik olarak hazırlanan rubriğin kullanılabilirliği ortaya konmuştur.

Bu araştırmada, geliştirilen rubriğin "kapsam geçerliği” Lawshe tekniğinden yararlanılarak uzman görüşleri aracılığıyla sağlanmış ve ölçeğin kapsam geçerlik indeksi 1 . boyut için $0,89,2$. boyut için 0,87 olarak hesaplanmıştır. Güvenirliği ise "bağımsız değerlendirmeciler arası uyum güvenirliği" ile sağlanmıştır. Yapılan analiz sonucunda 4 farklı değerlendirmecinin “içeriği anlama” kısmına ilişkin puan ortalamaları korelasyonu arasında çok yüksek, pozitif yönlü ve anlamlı bir ilişkinin olduğu görülmektedir $(p<.01)$. Değerlendirmecilerin "derinlemesine anlama/bakış" kısmına ilişkin puan ortalamaları korelasyonu arasında da çok yüksek, pozitif yönlü ve anlamlı bir ilişsinin olduğu görülmektedir ( $p<.01)$. Değerlendirmecilerin içeriği anlama ve derinlemesine bakış boyutundaki her bir 
kritere ilişkin puanlamaları arasında da fark olmadığı görülmektedir ( $p>05$ ). Yani farklı değerlendirmecilerin her bir soru için puanlama ortalamaları tutarlı, birbirine benzer ve puan ortalama farkları arasında anlamlı bir fark yoktur.

Eleştirel düşünmede en önemli unsur öğrencileri düşünmeye yönlendirecek sorulardır. Yapılan araştırmalar anlamayı değerlendirme sürecinde birçok öğretmenin basit anlamaya yani öğrencilerin ders kitaplarında veya notlarında bulunan bilgileri tanımlamaya, tekrar etmeye veya yorumlamaya yönelik sorular sorduğunu göstermektedir. Ancak öğrencilerin kişisel, akademik ve mesleki gelişimini geliştirerek onları hayata hazırlamak için açık uçlu sorularla/problemlerle uğraşmaları gerekmektedir (Lynch ve Wolcott, 2001, s. 2). Öğrencilerin bir konudaki önemli ve belirsiz noktaları dikkate alarak konuyu yorumlayabilmesi, olası çözümler üretebilmesi ya da ortaya çıkabilecek sonuçları değerlendirebilmesi Türkçe Dersi Öğretim Programı'nın da amaçları arasındadır.

Türkçe ders kitaplarına bakıldığında her ne kadar Türkçe Dersi Öğretim Programlarında (2006; 2017; 2018) öğrencilerin okuduklarını eleştirel bir gözle değerlendirebilmeleri hedeflense de ders kitaplarındaki soru tiplerinin bu amaca uygun olarak hazırlanmadığı söylenebilir. Akyol vd. (2014, s. 91), öğretmenlerin, öğrencilerin derinlemesine anlamalarını sağlayacak soruları kullanmadığını belirtmiştir. $\mathrm{Bu}$ da eleştirel düşünme konusunda öğretmenlerin de eğitilmesi gerektiğini göstermektedir. Öğretmenlerin derslerde ve değerlendirmelerde öğrencilerin üst düzey düşünme becerilerini harekete geçirecek öğretim uygulamalarına yer vermemeleri, öğrencilerin PISA ve PIRLS gibi uluslararası sınavlardaki başarısızlığını da açıklamaktadır. PISA 2015 sonuçlarına göre üst düzey okuma becerilerine sahip öğrenci oranı OECD'de \%8,3, tüm ülkelerde \%5,6 iken Türkiye'de \%0,06'dır.

Ders kitaplarındaki okuma metinlerine soru hazırlanırken öğrencilere kazandırılmak istenen temel beceri kriterleri dikkate alınmalıdır. Ayrıca öğretmenler de eleştirel ve yaratıcı düşünmeyi sağlayan soru tipleri, bu soruların değerlendirilmesi ve bu becerileri ölçmeye yönelik ölçme aracı geliştirme konusunda eğitilmelidir. Türkçe ders kitaplarında dinleme, konuşma, okuma, yazma becerilerine yönelik değerlendirme formları yer alırken eleştirel düşünmeyle ilgili bir değerlendirme aracı bulunmamaktadır. Bu becerilerin değerlendirilmesinde kullanılacak ölçme araçlarının geliştirilerek Türkçe ders kitaplarında yer almasının uygun olacağı söylenebilir.

Antalya'da gerçekleştirilen Eğitim Liderleri Zirvesi'ne (2017) video konferansla bağlanan OECD PISA Direktörü Andreas Schleicher öğrencileri düşünmeye sevk edecek açık uçlu soruların ancak doğru bir değerlendirme ile amacına ulaşabileceğini belirtmiştir. Schleicher dünya genelinde uzun yıllar çoktan seçmeli soruların tercih edildiğini, ancak günümüzde artık öğrencinin kendi cevabını oluşturduğu açık uçlu sınavlara geçildiğini belirtmiştir. Schleicher, çoktan seçmeli soruların öğrencilerin farklı kriterdeki bilgilerini ölçmeye imkân vermediğini; açık uçlu soruların ise öğrencinin bilgisinin yanı 
sıra eleştirel, yaratıcı, analitik düşünme gibi farklı kriterlere göre ölçme-değerlendirme yapılmasına imkân tanıdığını ifade etmiştir. Ayrıca dünyada 10 yılı aşkın bir süredir açık uçlu sorulara yönelik büyük bir eğilim olduğunu, Türkiye'de son dönemlerde sınav sistemlerinde yapılan değişikliklerle açık uçlu sorulara yönelik eğilimin OECD ülkelerine benzer olumlu bir gelişme olduğunu belirtmiştir. Böyle bir sistemle öğretmenlerin, bilginin yeniden üretildiği soruları bir kenara bırakarak daha yaratıcı çalışmalara başlayacağını ve bunun için de değerlendirmeyi yapacak öğretmenlerin ve uzmanların çok iyi eğitilmesi gerektiğini vurgulamıştır (Birgün.net, 2017, e.t. 05.10.2018). Bu bakımdan değerlendirici objektifliğini sağlayacak geçerli ve güvenilir ölçme araçlarına ihtiyaç duyulmaktadır.

Yukarıda açıklanan işlemler ve analizler, geliştirilen rubriğin Türkçe derslerinde öyküleyici metinler aracılığıyla öğrencilerin eleştirel düşünme becerilerinin hangi kriterlere göre nasıl değerlendirileceğiyle ilgili geçerli, güvenilir ve kullanılabilir bir rubrik olduğunu göstermektedir. Hazırlanan rubrik, kriterleri yansıtan farklı soru kökleriyle (EK-1) farklı metinlerde kullanılabilir.

\section{Kaynaklar}

Akyol, H. (2014). Programa uygun Türkçe öğretim yöntemleri. Ankara: PegemA Yayıncılık.

Akyol, H., Yıldırım, K., Ateş, S., Çetinkaya, Ç. ve Rasinski, T. V. (2014). Okumayı değerlendirme-öğretmenler için kolay ve pratik bir yol. Ankara: PegemA Yayıncılık.

Allen, M. J. (2014). Using rubrics to grade, assess, and improve student learning. [Avaible online at: http://www.mdc.edu/sailearn/documents/4.1\%20Rubric\%20Workshop\%20HandoutMary\%20Allen.pdf], Retrieved on July 07, 2017.

Badger, E., \& Thomas, B. (1992). Open-ended questions in reading. Practical Assesment, Research \& Evaluation, 3(4), 1-3. [Avaible online at: http://pareonline.net/getvn.asp?v=3\&n=4], Retrieved on August 15, 2018.

Bahar, M., Nartgün, Z., Durmuş, S., ve Bıçak, B. (2014). Ölçme ve değerlendirme teknikleri öğretmen el kitabı. Ankara: PegemA Yayıncılık.

Beyreli, L. ve Arı, G. (2009). Yazma performansını değerlendirmede çözümleyici puanlama yönergesi kullanımıdeğerlendrimeciler arası uyum araştırması. Kuram ve Uygulamada Eğitim Bilimleri KUYEB/Educational Sciences: Theory \& Practice, 9(1), 85-125.

Brophy, T.S. (2018). Writing effective rubrics. University of Florida Institutional Assesment. [Avaible online at: http://assessment.aa.ufl.edu/Data/Sites/22/media/slo/writing_effective_rubrics_guide_v2.pdf], Retrieved on June 25, 2017.

Catalina Foothills School District (2015). Critical thinking and problem solving grade 6-8: Envision21 deep learning, Arizona. [Avaible online at: https://www.cfsd16.org/application/files/7214/7024/6209/CriticalThinkingProblemSolving.pdf], Retrieved on August 15, 2017.

Center for Teaching (2006). Critical thinking scoring rubric. [Avaible online at: http://www.eiu.edu/learninggoals/pdfs/KansasStUni-CriticalThinkingRubric.pdf], Retrieved on May 20, 2017.

Facione, P.A. (2015). Critical thinking: What is and why it counts. 1-30. [Avaible online at: https://www.insightassessment.com/Resources/Importance-of-Critical-Thinking/Critical-ThinkingWhat-It-Is-and-Why-It-Counts/Critical-Thinking-What-It-Is-and-Why-It-Counts-PDF], Retrieved on August 20, 2017. 
Halpern, D. F. (1999). Teaching for critical thinking: Helping college students develop the skills and dispositions of a critical thinker. New Directions for Teaching and Learning, 80, 69-74.

Karagöz, H. (2014). Bilişsel gelişim ve dil gelişimi. Binnur Yeşilyaprak (Ed.), Eğitim Psikolojisi Gelişim-ÖğrenmeÖğretim içinde (s. 84-122). Ankara: PegemA Akademi.

Karasar, N. (2012). Bilimsel araştırma yöntemi. Ankara: Nobel Yayıncılık.

King, A. (1995). Designing the instructional process to enhance critical thinking across the curriculum: Inquiring minds really do what to know: Using questioning to teach critical thinking. Teaching of Psychology, 22(1), 13-17.

Lawshe, C. H. (1975). A quantitative approach to content validity. Personel Psychology, 28, 563-565.

Learning Development (2010). Critical thinking. Plymouth University. [Avaible online at: https://www.plymouth.ac.uk/uploads/production/document/path/1/1710/Critical_Thinking.pdf], Retrieved on September 15, 2017]

Lynch, C. L., \& Wolcott, S. K. (2001). Helping your student develop critical thinking skills. Manhattan, Kansas: Wolcottlynch Associates, The Idea Center. [Avaible online at: http://www.ideaedu.org/Portals/0/Uploads/Documents/IDEA\%20Papers/IDEA\%20Papers/IDEA_Paper _37.pdf], Retrieved on June 15, 2017.

MacKnight, C. B. (2000). Teaching critical thinking through online discussion. Educause Quarterly, 4, 38-41.

McGartland, R.D., Berg-Weger, M., Tebb, S., Lee, E. S., \& Rauch, S. (2003). Objectifying content validity: Conducting a content validity study in social work research. Social Work Research, 27(2), 94-104.

MEB (2006). illköğretim Türkçe dersi $(6,7,8$.$) sınıflar öğretim programı. Ankara.$

MEB (2012). Ortaokul ve imam hatip ortaokulu okuma becerileri dersi programı. Ankara: Millî Eğitim Bakanlığı.

MEB (2016). PISA 2015 ulusal ön raporu. Ankara: Ölçme, Değerlendirme ve Sınav Hizmetleri Genel Müdürlüğü. [Çevrim-içi: http://odsgm.meb.gov.tr/test/analizler/docs/PISA/PISA2015_Ulusal_Rapor.pdf], Erişim tarihi: 10.01.2018.

MEB (2017). Türkçe dersi öğretim programı (illkokul ve Ortaokul 1, 2, 3, 4, 5, 6, 7 ve 8). Ankara: Millî Eğitim Bakanlığı. [Çevrim-içi:http://mufredat.meb.gov.tr/Dosyalar/201783142827263-turkce.pdf], Erişim Tarihi: 10.02.2018

MEB (2018). Türkçe dersi öğretim programı (illkokul ve Ortaokul 1, 2, 3, 4, 5, 6, 7 ve 8). Ankara: Millî Eğitim Bakanlığı. [Çevrim-içi: http://mufredat.meb.gov.tr/ProgramDetay.aspx?PID=332], Erişim Tarihi: 12.03.2018.

Mertler, C. A. (2001). Designing scoring rubrics for your classroom. Practical Assessment Research \& Evaluation, 7(25), 1-8. [Avaible online at: http://pareonline.net/getvn.asp?v=7\&n=25], Retrieved on July 20, 2018.

Moskal, B. M. (2000). Scoring rubrics: what, when and how?. Practical Assessment, Research \& Evaluation, 7(3), 1-6. [Avaible online at: http://northweststate.edu/wp-content/uploads/files/MoskalScoringRubrics.pdf], Retrieved on July 24, 2017.

Moskal, B. M., \& Leydens, J. A. (2000). Scoring rubric development: Validity and reliability. Practical Assesment Research \& Evaluation, 7(10), 1-6.

Öztürk, D. ve Güdek, B. (2016). Viyolonsel performans değerlendirmesine yönelik dereceli puanlama anahtarının (rubrik) geliştirilmesi. Akademik Müzik Araştırmaları Dergisi AMADER, 2(3), 1-20.

Paul, R., \& Elder, L. (2006). The miniature guide to critical thinking: Concepts and tools. The Foundation for Critical Thinking. [Avaible online at: https://www.criticalthinking.org/files/Concepts_Tools.pdf], Retrieved on August 25, 2018. 
Peirce, W. (2006). Designing rubrics for assessing higher order thinking. [Avaible online at: http://academic.pg.cc.md.us/ wpeirce/MCCCTR/Designingrubricsassessingthinking.html], Retrieved on May 20, 2017.

PISA'dan Açık Uçlu Soru Uyarısı: Öğretmenler İyi Eğitilmeli! (2017, Ekim 5). BirGün Gazetesi, [Çevrim-içi: https://www.birgun.net/haber-detay/pisa-dan-acik-uclu-soru-uyarisi-ogretmenler-iyi-egitilmeli182801.html], Erişim Tarihi: 15.10.2018.

Roberts, J. E. (2008). Developing rubrics. Northern Virginia Community College. [Avaible online at: https://www.nvcc.edu/assessment/_docs/PS6.developingrubricspresentation.pdf], Retrieved on June 25, 2017.

Schmit, J. S. (2002). Practicing critical thinking through inquiry into literature. In J. Holden, \& J. S. Schmit (Eds.), Inquiry and the literacy text: Constructing discussions in the English classroom. Classroom practicing in teaching English. 32, Urbana: National Council of Teachers of English.

Willingham, D. T. (2007). Critical thinking: Why is it so hard to teach. American Educator. 8-19 [Avaible online at: https://www.aft.org/sites/default/files/periodicals/Crit_Thinking.pdf], Retrieved on August 12, 2017.

Yıldırım, A. ve Şimşek, H. (2013). Sosyal bilimlerde nitel araştırma yöntemleri. Ankara: Seçkin Yayıncılık.

Yurdagül, H. (2005). Ölçek geliştirme çalışmalarında kapsam geçerliği için kapsam geçerlik indekslerinin kullanılması. XVI. Ulusal Eğitim Bilimleri Kongresi (28-30 Eylül), Denizli.

\section{Extended Abstract}

Introduction

Critical thinking is the assessment of the process of thinking about how a good decision is made about a topic or how a problem is solved in a good way. Such a definition is broad enough to encompass a variety of perspectives. Therefore, critical thinking; problem-solving, decision-making, analyzing, or taught as cognitive processes. The common feature of these approaches is that critical thinking is a skill that can be taught and learned. Students become a good "critical thinker" when they learn and apply these skills correctly.

One of the most important things in teaching critical thinking is teaching students how to think. In addition, it is also important to establish and apply the preliminary knowledge of the students about the subject. In this respect, teachers should support their students with classroom practices and help them to think critically independently.

Today's students are expected to learn from what they have learned and that they are individuals who are able to think with reasons. In this study, open-ended questions were prepared in specific performance criteria in order to enable students to understand the content of a text they read in their Turkish lessons and to think in depth, and applications were made to develop students' critical thinking skills. In order to evaluate these applications, an analytical (pertaining to analysis) critical thinking rubric, which consists of two dimensions, namely reading comprehension and critical thinking, has been prepared for use in narrative texts. Thus, a rubric was prepared for determining the types of questions to be used in the evaluation of critical thinking skills through the narrative texts in Turkish lessons, the performance evaluation criteria, the qualification levels and how to define the criterion levels and the usability of the rubric was demonstrated.

\section{Method}

The study is a qualitative study based on expert opinion. This process has been transformed into a quantitative process with scope validity and inter-rater agreement. The study group was determined as middle school students with criterion sampling. The pilot application of the rubric was done before the application. Pilot application was made with 40 students and 6 Turkish teachers. Before the reliability study, the last version of the rubric was tested with 110 students. For the validity, 5 experts and 4 Turkish teachers were employed. The content validity of the scale was made by Lawshe technique. The content validity index (CVI) of the content comprehension dimension is 0.89 ; the size of the in-depth comprehension was calculated as 0.87 . The reliability of the study is ensured by the "independent evaluator interdependency reliability". For reliability among 652 papers, 202 obtained data were evaluated by 4 different Turkish teachers. As a result of Pearson's correlation analysis, it is seen that there is a very high, positive and significant correlation between the scores average correlations of the four different evaluators' critical thinking criteria $(p<.01)$. The ANOVA analysis showed that there was no difference between the scores of each criterion in the critical thinking skills of the evaluators ( $p>$ $.05)$.

\section{Result and Discussion}


As a result of the analysis made, the point average correlations between the content comprehension criteria of the 4 different evaluators are 1-2. (0, 981), 1-3. (0.991), 1-4. (0.995); 2-3. (0, 975), 2-4. (0.977); 3-4. (0.987) were found to be very high, positive and meaningful $(p<.01)$. Correlation of the points related to the indepht comprehension criterion of the evaluators is 1-2. $(0,961), 1-3$. (0.980), 1-4. (0.993); 2-3. (0,943), 2-4. (0.955); 3-4. (0.976) were found to be very high, positive and meaningful $(p<.01)$. There is also no difference between the scores for each criterion in the dimension of content comprehension and in-depht copmrehension read by evaluators ( $p>$.05). That is, the scoring averages for each question of different evaluators are consistent, similar, and there is no significant difference between average point differences.

The above-mentioned processes and analyses show that the developed rubrics are valid, reliable and usable rubrics in which the critical thinking skills of the students are evaluated according to the criteria through narrative texts in Turkish lessons.

EK-1: Türkçe Derslerinde Eleştirel Düşünmeye Yönelik Beceriler ve Soru Örnekleri/Kökleri

\begin{tabular}{|c|c|c|}
\hline Beceriler & Alt Beceriler & Sorular \\
\hline $\begin{array}{l}\text { Tanımlama: Konuyu } \\
\text { belirleme, tanıtma ve } \\
\text { problemi/konuyu önceki } \\
\text { bilgilerle birlikte ele alma. }\end{array}$ & $\begin{array}{l}\text { - belirleme, } \\
\text { - tarif etme, } \\
\text { - siniflama, } \\
\text { - siralama, } \\
\text { - seçme, } \\
\text { - betimleme. }\end{array}$ & $\begin{array}{l}\text { - Kim? } \\
\text { - Ne? } \\
\text { - Nerede? } \\
\text { - Nasıl? } \\
\text { - Ne zaman? } \\
\text { - ...yı tanımlayınız. }\end{array}$ \\
\hline $\begin{array}{l}\text { Yorumlama: } r \text { ilkelerin, } \\
\text { olguların neden, niçin ve nasıl } \\
\text { olduğunu açıklama. } \\
\text { (Öğrencinin konuya ilişkin } \\
\text { örnek vermesi ve konudan ne } \\
\text { anladığını } \quad \text { yorumlaması } \\
\text { beklenir.) }\end{array}$ & $\begin{array}{l}\text { - } \text { metindeki ilişkileri } \\
\text { - } \text { açıklama, } \\
\text { fenzerlik ve } \\
\text { belirlıme, } \\
\text { - karşılaştırma } \\
\text { yapma, } \\
\text { - örnek verme, } \\
\text { - özetleme, } \\
\text { - anlamı açıklama. }\end{array}$ & $\begin{array}{l}\text { - Bu metnin ana fikrini / yardımcı fikirlerini } \\
\text { açıklayınız? } \\
\text { - Verilmek istenen mesaj nedir? } \\
\text { - } \quad \text {... ne anlama gelmektedir? } \\
\text { - ...yla anlatılmak istenen nedir? } \\
\text { - ...ya örnek veriniz? }\end{array}$ \\
\hline 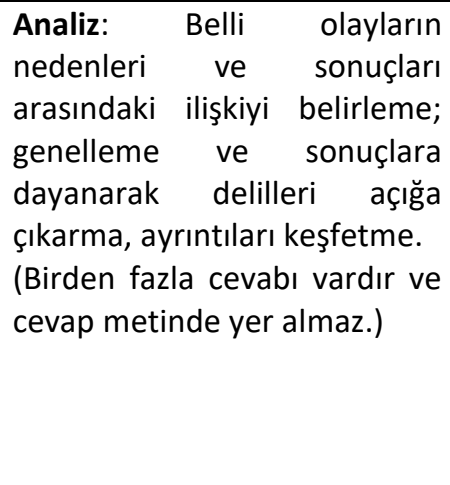 & $\begin{array}{l}\text { - } \text { parçalara ayırma, } \\
\text { - olgular arası } \\
\text { ilişkileri belirleme, } \\
\text { - gerekçelendirme, } \\
\text { - farklılığı bulma, } \\
\text { - destekleme. }\end{array}$ & $\begin{array}{l}\text { - } \text { Neden? / Niçin? / Nasıl? } \\
\text { - } \quad . . \text { nın ... üzerindeki etkisini belirtiniz. } \\
\text { - } \quad \text {..., ...yı nasıl etkiler? } \\
\text { - } \quad \text {...nın gerekçeleri / sonuçları nelerdir? } \\
\text { - } \quad \text {...nın sebep-sonuçları nelerdir? } \\
\text { - ...nın ...ya benzeyen /...nın ...dan farklı olan } \\
\text { yanları nelerdir? } \\
\text { - ...yla ... arasında nasıl bir ilişki/bağlantı var? } \\
\text { - ..., ...ya nasıl uyarlanabilir? } \\
\text { - ... arasındaki karşıtlıklar / benzerlikler nasıl } \\
\text { kurulmuştur? }\end{array}$ \\
\hline $\begin{array}{lcr}\text { Çıkarım: } & \text { Eldeki } & \text { verilerin } \\
\text { analizini } & \text { yaparak } & \text { sonuca } \\
\text { ulaşma. } & & \\
& & \end{array}$ & $\begin{array}{l}\text { - bir sonuca varma, } \\
\text { karar verme, } \\
\text { tanımlama, } \\
\text { alternatif sunma, } \\
\text { genelleme yapma, } \\
\text { planlama, tahmin } \\
\text { etme vb. için } \\
\text { ipuçlarından ve } \\
\text { belli standartlardan } \\
\text { yararlanma. }\end{array}$ & $\begin{array}{l}\text { - ...dan hangi sonucu çıkartıyorsunuz? } \\
\text { - ...dan çıkardığınız sonuç nedir? }\end{array}$ \\
\hline
\end{tabular}




\begin{tabular}{|c|c|c|}
\hline $\begin{array}{l}\text { Açıklama: Sonuç çıkarma, } \\
\text { sorgulama, anlamı belirleme, } \\
\text { görüş sunma gibi düşünme } \\
\text { süreçlerini tekrar anlatabilme. }\end{array}$ & $\begin{array}{l}\text { - } \text { sonuçları belirtme, } \\
\text { - yapılan şeyleri } \\
\text { savunma, } \\
\text { - görüş sunma. }\end{array}$ & $\begin{array}{l}\text { - } \text { Araştırmanın sonuçları ve belli bulguları } \\
\text { nelerdir? } \\
\text { - } \text { Bu analize nasıl ulaştığınızı açıklayınız. } \\
\text { - } \text { Bu çıkarıma nasıl ulaştığınızı açıklayınız? } \\
\text { - Gerekçelerinizi bize bir kez daha anlatınız. } \\
\text { - } \quad \text { Neden böyle düşündünüz? Niçin böyle bir } \\
\text { karar verdiğinizi nasıl açıklarsınız? }\end{array}$ \\
\hline $\begin{array}{l}\text { Varsayımda Bulunma: Tahmin } \\
\text { etme, öngörüde bulunma, } \\
\text { alternatif sunma. }\end{array}$ & $\begin{array}{l}\text { - tahmin etme, } \\
\text { - önerme. }\end{array}$ & $\begin{array}{l}\text { - ... olursa, ne olur? } \\
\text { - ... olsaydı, ne farklı olurdu? } \\
\text { - ... görüşüyle ilgili tahminlere göre neler } \\
\text { olacak? } \\
\text { - ... olsaydı/olmasaydı ne olurdu? }\end{array}$ \\
\hline $\begin{array}{lr}\text { Değerlendirme: } & \text { Kanıtların, } \\
\text { fikirlerin, varsayımların, } & \text { önyargıların, görüşlerin, bakış } \\
\text { oçılarının vb.nin } & \text { geçerliliğini, } \\
\text { etkililiğini, } & \text { önemini, } \\
\text { avantajlarını, } & \text { haklılığını, } \\
\text { etkisini, } & \text { gerçekliğini } \\
\text { değerlendirme. }\end{array}$ & $\begin{array}{l}\text { - karar verme, } \\
\text { - değer biçme } \\
\text { - önemini belirleme, } \\
\text { - doğrulama } \\
\text { - katılma/katılmama, } \\
\text { - bakış açısı } \\
\text { geliştirme }\end{array}$ & $\begin{array}{l}\text { - ...nın iyi veya kötü olduğunu düşünüyor } \\
\text { - } \text { musun? Neden? } \\
\text {...nın doğşünüyor musun? Neden? } \\
\text { - ... hakkındaki düşüncelerin neler? } \\
\text { - ...ya katıldığın / katılmadığın yerler neler? } \\
\text { - ... olsaydı nasıl hissederdin? } \\
\text { - ...nın lehine ve aleyhine olan şeyler neler? } \\
\text { - ...yla ilgili probleme / konuya / } \\
\text { anlaşmazlığa bulunacak en iyi çözüm } \\
\text { nedir? Neden? }\end{array}$ \\
\hline
\end{tabular}

\section{EK-2: Uygulamada Kullanılan Örnek Metin ve Soruları}

\section{Bir Kavak ve İnsanlar}

“Kavağın altına..." demişti, "Beni, o sahildeki kavağın altına gömün!”

Kavak zaten kulübesinin uzağında değildi. Sahile bakan dik yamacın üstünde, dağ çilekleriyle böğürtlenlerin sarmaş dolaş oldukları vahşi bir kırlığın ortasında idi. İhtiyar, elinde tespihi, her akşam onun altında oturur; aşağıda denizin kumluğu tatlı tatlı yalayışını seyrederdi. İşte şimdi, mezarını yine o kavaklığın gövdesi gölgeleyecek, yine dalgalar ayak ucunda o çok sevdiği besteyi söyleyecekti. Böylece yaz geçti. Güz geçti. Kış geçti. Illkbahar gelip de mayıs güneşi ılık nefesini tabiata hohlayınca, bademler birden beyazlara büründü. Kırlar kokularını süründü. Deniz aniden duruldu. O sakin mavisini yeniden buldu. Bu arada ihtiyar kavak da tomurcuklanıp yaprak açmıştı.

Fakat köylüler bu bahar onda tuhaf bir değişiklik keşfediyorlardı. Hayır, hayır; bu, sade yapraklanmaktan ileri gelen o her yılki alışılmış değişiklik değildi... Bu öyle kolay kolay anlaşılamayan, kesin olarak saptanamayan ancak ve ancak sezilebilen bir bambaşka, bir acayip gelişme idi. Kavakta şimdi, o, bitkilere özgü görünüşten fazla bir şey, âdeta insanlara has bir şey, nasıl söylemeli, sanki bir tür kimlik belirmekte idi. Kadınlardan biri: "ihtiyar" diye haykırdı, "ihtiyara benziyor kavak." Gerçekten de kavak, sanki altında yatan ihtiyarın bütün özünü kökleriyle emip gövdesine geçirmişe benziyordu. Şekil itibariyle yine aynı ağaçtı belki; fakat insan ona bakarken o uzun boylu, zayıf ihtiyarı görmüş gibi oluyordu. Tevekkeli, oraya gömülmek istemişti adam. İşte ne yapmış yapmış, ruhunu ağaca verip kendini o çok sevdiği yeryüzüne atmanın yolunu bulmuştu. Hem böylece tabiatı daha yakından, olanca görkemiyle tadabilecekti artık... Nitekim şimdi, sağlığında iken yapamadıklarını yapıyor; nezle, bronşit korkusu olmaksızın göğsünü, yaz yağmurunda ıslatıp akşam rüzgârında kurutuyordu.

Eski dostlarının bu suretle tekrar aralarına karışması, sade köylüleri değil, kuşları, bulutları, çiçekleri, rüzgârları, kısacası bütün tabiatı da sevinçlere boğdu. Fakat hangi mutluluk sonsuza kadar sürmüş ki? Bir sabah yapraklarındaki çiy damlalarını silkeleyip kurulanan kavak, az ötesinde birtakım insanların eğilip kalkıp yerleri ölçtüklerini gördü. Adamlar öğle vakti gelip onun altında oturdular. Elindeki planlardan mimar olduğu anlaşılan bir tanesi, üç katlı ensesinden mal sahibi olduğu anlaşılan bir başkasına:

"Makine dairesi şurada olacak, laboratuvarlar beri yanda kurulacak, lojmanlar ise batı cephesine rastlayacak." diye açıklamada bulunuyordu. Kavak gerisini dinlemedi. Bu duyduğu sözlerden yaprakları diken diken olmuştu. Demek, burada fabrika kuracaklardı. Demek, bu cennet kıyıları, bu canım bayırları makine 
uğultusuna, kurum kokusuna boğacaklardı. Dünyada başka yer mi kalmamıştı, ya Rabbim! Maliyet fiyatı diyor da gözleri başka bir şey görmüyordu. Maliyet fiyatı ise bu sahilde çok düşük olacaktı. Bundan dolayı...

ilkkin sahile bir iskele kurdular. Malzeme deniz yoluyla daha ucuza nakledilecekti. Sonra bir mendirek inşa edip denizle sahilin ilişkisini kestiler. Dalgalar artık suları tatlı tatlı okşamaz olmuştu. Mendireğin içinde kalan miskin, ölü sulara ise deniz demeye bin şahit isterdi. Yalnız deniz mi ya, çiçekler de durumdan şikâyetçiydiler. Papatyalar kurumdan simsiyah oluyorlardı. Gelinciklerin kırmızısı ise isli çatana bayraklarına dönmüştü.

Kuşların cıvıltısı, şantiyeden yükselen çekiç sesleri arasında güme gittiğinden, onlar da birleşip koro hâlinde ötmeyi denediler. Fakat bu gürültülü medeniyet konseri ile baş edemeyeceklerini anlayınca, sonunda onlar da küsüp ötmemeye karar verdiler. Hem zaten pazarları gıcır gıcır çifteleri ile ava çıkan şantiye mühendisleri hayatı onlara zehir etmeye başlamıştı. Kuşlar küsüp, deniz susup, çiçekler de solunca, kavak öksüze döndü. "Bir yıldırım gelse de beni de yok etse bari!” diye kötü kötü düşündüğü oluyordu. Fakat yıldırıma hacet kalmadı. Bir sabah, daha uykuda iken, belinde keskin bir testere sızısı ile uyandı. Ve neye uğradığını anlamadan yan üstü böğürtlenlerin üzerine devriliverdi.

Ötede bir ses, fabrikatörün sesi:

"Günah da ne demekmiş?” diye bağırıyordu: "Bize ağaç değil, yer lâzım yer... Zaten neye benziyordu? Tek başına, sipsivri bir ağaçtı." Sonra emri altındaki mühendislere dönüp: "Bundan çok güzel telefon direği olur." dedi.

Ve ihtiyar kavak soyuldu, yontuldu. Diğer direkler gibi toprağa girecek kısmı ziftlendi. Bu işler bitince üzerine bir parmak kalınlığında boya sürülüp tepesine de külâh gibi çinko bir başlık geçirildikten sonra ana şebekeyi fabrika santraline bağlayan yola, öbür direklerin arasına dikildi.

Haldun TANER

Hikâyeler (Kısaltılmıştır.)

\section{Sorular}

1. Aşağıdaki soruları metne göre cevaplayınız.

a. Okuduğunuz metinde anlatılan olay nedir? (Tanımlama)

b. Hikâyenin ana kahramanı kimdir? (Tanımlama)

c. Hikâyede anlatılanlar hangi mevsimde gerçekleşmiştir? (Tanımlama)

d. Hikâyenin geçtiği yerin özellikleri nasıldır? (Tanımlama)

2.a. Ihtiyarın, öldüğünde kavak ağacının altına gömülmeyi neden istediğini kendi cümlelerinizle yazınız. (Yorumlama)

2.b. Yazar, "Fakat (kuşlar) bu gürültülü medeniyet konseri ile baş edemeyeceklerini anlayınca, sonunda onlar da küsüp ötmemeye karar verdiler." cümlesinde altı çizili kısımla anlatılmak istenen nedir? Sizce neden böyle bir benzetme yapılmış olabilir? (Yorumlama)

2.c. Okuduğunuz metnin ana düşüncesi nedir? Bu düşünceye metindeki hangi ipuçlarını kullanarak ulaştınız? (Yorumlama)

3. Ormanların yok edilerek yerine fabrikaların yapılmasının, çevredeki diğer canlıları (insanları, hayvanları, bitkileri vb.) nasıl etkilediğini gerekçeleriyle birlikte ayrı ayrı örneklendiriniz. (Analiz)

4. Bu parçadan hangi sonuçları çıkarıyorsunuz? Bu sonuca nasıl ulaştığınızı gerekçesiyle yazınız. (Çıkarım)

5. Sizce fabrika, baraj gibi sanayi kuruluşlarının çevreye zarar vermeden kurulup işletilmesinin yolları nelerdir? Örneklerle açıklayınız. (Açıklama)

6. Fabrikatör kavak ağacını kesmeseydi sizce olaylar nasıl gelişirdi? Niçin böyle bir varsayımda bulunduğunuzu gerekçesiyle yazınız. (Varsayımda bulunma)

7. Metinde anlatılan çevre sorununa bulunabilecek en iyi çözüm şekli sizce ne olmalıdır, gerekçesiyle yazınız. (Değerlendirme)

\section{EK-3: Öyküleyici Metinler İçin Analitik Eleştirel Düşünme Rubriği}

- Yönerge: Bu rubrik öyküleyici metinler aracılığıyla öğrencilerin eleştirel düşünme becerisini değerlendirmek için hazırlanmıştır. Rubriğin tanımlama ve yorumlama kriterleri öğrencilerin içeriği anlama; analiz, çıkarım, açıklama, varsayımda bulunma; değerlendirme kriterleri ise derinlemesine anlama becerilerini değerlendirmeye yöneliktir. Ölçeğin uygulama kısmında öğrencilerden ölçme aracına uygun kriterleri karşılayan bir metni okuduktan sonra bu metinle ilgili kriterleri karşılayan açık uçlu sorulara cevap vermeleri istenir. Öğrencilerin sorulara vermiş olduğu cevaplar ölçeğe göre değerlendirilir. 


\begin{tabular}{|c|c|c|c|}
\hline \multirow{5}{*}{ 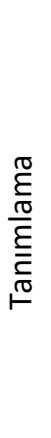 } & \multirow{5}{*}{ A } & (4) Oldukça yeterli & $\begin{array}{l}\text { Olay (1.a), şahıs kadrosu (1.b), zaman (1.c.) ve yerle (1.d) ilgili unsurların } \\
\text { tamamını doğru belirler. }\end{array}$ \\
\hline & & (3) Yeterli & Olay, şahıs kadrosu, zaman ve yerle ilgili unsurların çoğunu doğru belirler. \\
\hline & & (2) Geliştirilebilir & Olay, şahıs kadrosu, zaman ve yerle ilgili unsurların yarısını doğru belirler. \\
\hline & & (1) Az yeterli & $\begin{array}{l}\text { Olay, şahıs kadrosu, zaman ve yerle ilgili unsurlardan } \underline{1 \text { tanesini doğru }} \\
\text { belirler. }\end{array}$ \\
\hline & & (0) Yetersiz & Olay, şahıs kadrosu, zaman ve yerle ilgili unsurlarını belirleyemez. \\
\hline \multirow{15}{*}{ 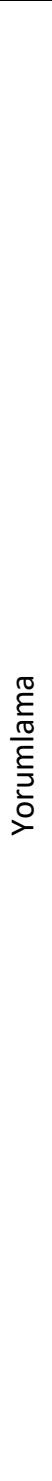 } & \multirow{5}{*}{ B } & (4) Oldukça yeterli & $\begin{array}{l}\text { Olaylar arasındaki anlam ilişkilerini (sebep-sonuç, amaç-sonuç, } \\
\text { karşılaştırmalar vb.) kendi cümleleriyle tam ve doğru olarak belirler. (2.a) }\end{array}$ \\
\hline & & (3) Yeterli & $\begin{array}{l}\text { Olaylar arasındaki anlam ilişkilerini metindeki ifadeleri tekrar ederek tam } \\
\text { ve doğru olarak belirler. }\end{array}$ \\
\hline & & (2) Geliştirilebilir & Olaylar arasındaki anlam ilişkilerini kısmen belirler. \\
\hline & & (1) Az yeterli & Olaylar arasındaki anlam ilişkilerini yanlış belirler. \\
\hline & & (0) Yetersiz & Olaylar arasındaki anlam ilişkilerini belirleyemez. \\
\hline & \multirow{5}{*}{$\mathrm{C}$} & (4) Oldukça yeterli & $\begin{array}{l}\text { Metindeki örtülü ifadelerin ne anlama geldiğini gerekçesiyle birlikte } \\
\text { belirler. (2.b.) }\end{array}$ \\
\hline & & (3) Yeterli & Metindeki örtülü ifadelerin ne anlama geldiğini belirler. \\
\hline & & (2) Geliştirilebilir & Metindeki örtülü ifadelerin ne anlama geldiğini kısmen belirler. \\
\hline & & (1) Az yeterli & Metindeki örtülü ifadelerin ne anlama geldiğini yanlıș belirler. \\
\hline & & (0) Yetersiz & Metindeki örtülü ifadelerin ne anlama geldiğini belirleyemez. \\
\hline & \multirow{5}{*}{ D } & (4) Oldukça yeterli & $\begin{array}{l}\text { Metindeki ipuçlarından en az iki tanesini kullanarak ulaştığı ana } \\
\text { düşünceyi tam ve doğru olarak belirler. (2.c.) }\end{array}$ \\
\hline & & (3) Yeterli & $\begin{array}{l}\text { Metindeki ipuçlarından birini kullanarak ulaştığı ana düşünceyi tam ve } \\
\text { doğru olarak belirler. }\end{array}$ \\
\hline & & (2) Geliştirilebilir & Ana düşünceyi tam ve doğru olarak belirler. \\
\hline & & (1) Az yeterli & Ana düşünceyi kısmen belirler. \\
\hline & & (0) Yetersiz & Ana düşünceyi belirleyemez. \\
\hline \multirow{2}{*}{ 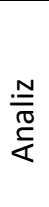 } & \multirow{2}{*}{$\mathrm{E}$} & (4) Oldukça yeterli & $\begin{array}{l}\text { Kavramlar veya olgular arasındaki ilişkiyi gerekçelendirirken örnekleri } \\
\text { yeterli sayıda kullanır. }\end{array}$ \\
\hline & & (3) Yeterli & $\begin{array}{l}\text { Kavramlar veya olgular arasındaki ilişkiyi gerekçelendirirken örnek } \\
\text { kullanır. }\end{array}$ \\
\hline
\end{tabular}




\begin{tabular}{|c|c|c|c|}
\hline & & (2) Geliştirilebilir & $\begin{array}{l}\text { Kavramlar veya olgular arasındaki ilişkiyi genel olarak kurar ama gerekçe } \\
\text { bildiremez. }\end{array}$ \\
\hline & & (1) Az yeterli & $\begin{array}{l}\text { Kavramlar veya olgular arasında metinle ilgisiz veya kısmen ilgili ilișkiler } \\
\text { kurar veya kavramlar ve olgular arasındaki ilişkiyi metindeki örnekleri } \\
\text { tekrar ederek kurar. }\end{array}$ \\
\hline & & (0) Yetersiz & Kavramlar veya olgular arasında ilişki kuramaz. \\
\hline \multirow{5}{*}{$\frac{\xi}{\frac{E}{\frac{E}{\pi}}}$} & \multirow{5}{*}{$\mathrm{F}$} & (4) Oldukça yeterli & Metinle ilgili çıkarımları gerekçesiyle sunar. \\
\hline & & (3) Yeterli & Metinle ilgili çıkarım yapar ve gerekçesini sunar. \\
\hline & & (2) Geliştirilebilir & Metinle ilgili çıkarım(lar) yapar ama gerekçe sunamaz. \\
\hline & & (1) Az yeterli & Metinle ilgisiz veya kısmen ilgili çıkarım(lar) yapar ama gerekçe sunamaz. \\
\hline & & (0) Yetersiz & Metinle ilgili çıkarım yapamaz. \\
\hline \multirow{5}{*}{ 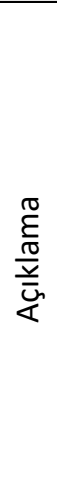 } & G & (4) Oldukça yeterli & $\begin{array}{l}\text { Metinle ilgili açıklamalarını uygun örneklerle destekleyerek yaratıcı ve } \\
\text { alternatif bir bakış açısıyla ifade eder. }\end{array}$ \\
\hline & & (3) Yeterli & $\begin{array}{l}\text { Metinle ilgili açıklamalarını uygun örneklerle ayrıntılı bir biçimde ifade } \\
\text { eder. }\end{array}$ \\
\hline & & (2) Geliştirilebilir & Metinle ilgili açıklamalarını uygun örneklerle genel olarak ifade eder. \\
\hline & & (1) Az yeterli & $\begin{array}{l}\text { Metinle ilgili açıklamalarını ilgisiz veya kısmen uygun örneklerle ifade } \\
\text { eder. }\end{array}$ \\
\hline & & (0) Yetersiz & Metinle ilgili açıklama yapamaz. \\
\hline \multirow{5}{*}{ 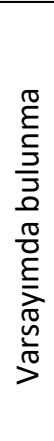 } & \multirow{5}{*}{$\mathrm{H}$} & (4) Oldukça yeterli & $\begin{array}{l}\text { Verilen durumla ilgili yaratıcı, alternatif ve mantıklı varsayım(lar)ını } \\
\text { gerekçeleriyle sunar. }\end{array}$ \\
\hline & & (3) Yeterli & Verilen durumla ilgili mantıklı varsayım(lar)ını gerekçeleriyle sunar. \\
\hline & & (2) Geliştirilebilir & Verilen durumla ilgili varsayım(lar)ını gerekçesiz olarak sunar. \\
\hline & & (1) Az yeterli & $\begin{array}{l}\text { Verilen durumla ilgisiz veya kısmen ilgili varsayımlarını gerekçesiz olarak } \\
\text { sunar. }\end{array}$ \\
\hline & & (0) Yetersiz & Verilen durumla ilgili varsayımda bulunamaz. \\
\hline \multirow{3}{*}{ 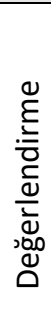 } & \multirow{3}{*}{$\mathrm{J}$} & (4) Oldukça yeterli & $\begin{array}{l}\text { Verilen durumla ilgili değerlendirmelerini yaratıcı ve alternatif bir bakış } \\
\text { açısıyla gerekçeli bir şekilde ifade eder. }\end{array}$ \\
\hline & & (3) Yeterli & Verilen durumla ilgili değerlendirmelerini mantıklı gerekçelerle ifade eder. \\
\hline & & (2) Geliştirilebilir & $\begin{array}{l}\text { Verilen durumla ilgili değerlendirmelerini kısmen mantıklı gerekçelerle } \\
\text { ifade eder veya verilen durumla ilgili birden fazla görüş belirtir ancak } \\
\text { gerekçe sunamaz. }\end{array}$ \\
\hline
\end{tabular}




\begin{tabular}{|l|l|l|l|}
\hline & & $\begin{array}{l}\text { (1) Az yeterli } \\
\text { gerilen durumla ilgili değerlendirmelerini mantığa uvgun olmavan } \\
\text { gerekcelerle ifade eder veya verilen durumla ilgili tek yönden ve genel bir } \\
\text { görustir ancak gerekçe sunamaz. }\end{array}$ \\
\cline { 2 - 3 } & (0) Yetersiz & Verilen durumla ilgili değerlendirme yapamaz. \\
\hline
\end{tabular}

